\title{
Two Petitions Concerning Civic Magistracies by a Gymnasiarch and Son of a Veteran
}

P.CtYBR inv. 505, housed in Yale University's Beinecke Library, is a rectangular piece of papyrus preserving on its two sides the ends of two respective petitions by the same individual, Quintus Marinus Claudianus, who was a gymnasiarch of Oxyrhynchus and the son of a veteran. The front carries a draft petition concerning appointments to municipal magistracies addressed to a prefect of Egypt. On the back was copied another petition concerning the financing of spectacles by magistrates for a local festival, together with the official response. This petition was probably also submitted to a prefect, but he referred it to the deputy epistrategus for a decision. The draft and copy on the respective sides are written in different hands, and as far as we can tell from what survives, there does not seem to be any obvious connection between the subjects of the two petitions. These texts provide an interesting window on some of the challenges facing civic magistracies in the towns of Roman Egypt in the late second century CE and state authorities' responses to them as well as new evidence for related imperial constitutions. They also present us with the son of a veteran who held an unusually high status compared to most veterans and their descendants in Roman Egypt.

The Oxyrhynchite provenance of the papyrus is guaranteed by the attestation of the petitioner in P.Oxy. XII 1541.5-6 (192) and by the mention of the local festival of Tybi (see $24-5$ n.). The exact dates of the petitions, however, are uncertain. They both follow the end of Sempronius Liberalis' prefecture in 159, since he is referred to as an exprefect in both texts $(\mathbf{1} 9,11 ; 29) .{ }^{1} \mathbf{1}$ must date from after 161 , because it cites a constitution of the emperors Marcus Aurelius and Lucius Verus. Their qualification as (gods) in 18 may, but need not, imply that they are dead, so that it cannot be taken as a decisive criterion for dating the petition after March 180 (see the note ad loc.). The official subscription in $\mathbf{2} 11$ is dated to 6 Pharmouthi of an anonymous ninth regnal year. Since the petitioner is attested as late as 192 in P.Oxy. 1541, the only viable possibilities are the ninth year of Marcus Aurelius and Verus $=1$ April 169 and the ninth year of

\footnotetext{
${ }^{1}$ On Marcus Sempronius Liberalis, prefect of Egypt from 154 to 159, see FAORO 2016, 106-8. The precedent cited in 2 8-10 does not imply that the petitioner was in office as gymnasiarch under Liberalis.
} 
Septimius Severus and Antoninus $=1$ April 201. ${ }^{2}$ The next ninth regnal year is that of Alexander Severus and would take us to 1 April 230, which is clearly too late. Although the year 201 is closer to the petitioner's only other attestation in P.Oxy. 1541 (192), the citation of a constitution of Marcus Aurelius and Verus in $\mathbf{1}$ and the references to Sempronius Liberalis in both petitions may suggest a date nearer to the latter's term of office as prefect. It is well known, however, that decisions of former prefects could still be cited several decades after they were first issued, ${ }^{3}$ and the designation of the emperors as $\theta \varepsilon o$ in in $\mathbf{1}$ remains ambiguous. In the Appendix, I raise but ultimately reject the possibility that the second petition was addressed to the emperor Septimius Severus when he visited Egypt at the turn of the third century.

According to the online catalogue of the Beinecke Library, the papyrus was purchased by M. I. RostovtzefF and C. B. Welles early in 1931 (before 10 February) from a dealer in Cairo named «Dr KondiLIOS». ${ }^{4}$

\footnotetext{
${ }^{2}$ Verus died early in 169 and is last attested in dating clauses of Egyptian papyri on 11 May of that year; see GONIS (2009), correcting SPP XXII 109.3-4. The fact that 2 was copied after the drafting of $\mathbf{1}$ does not necessarily imply that it is of later date, since it is possible to imagine someone copying an older document in support of a recent case.

${ }^{3}$ See HAENSCH 1992, 233: «Es wurden z. B. Entscheidungen von Statthaltern benutzt, die vor 17, 34, 35, 58 oder sogar 121 Jahren amtiert hatten.»

${ }^{4}$ Information from http://beinecke.library.yale.edu/research/library-catalogs-databases/guide-yale-papyruscollection\#Acquisition (accessed on 20 February 2017). I would like to thank RAYMOND CLEMENS, Curator for Early Books and Manuscripts at the Beinecke, and ANNE MARIE MENTA, Reproductions Co-ordinator, for supplying me with a high-resolution image of the papyrus. I am also very grateful to DIETER HAGEDORN for helpful comments on a draft of this article as well as to RUDOLF HAENSCH and the anonymous referee for some invaluable suggestions and corrections.
} 
The lower portion of a draft petition to the prefect of Egypt (cf. 3 cou Tìv ácúvKpıтov

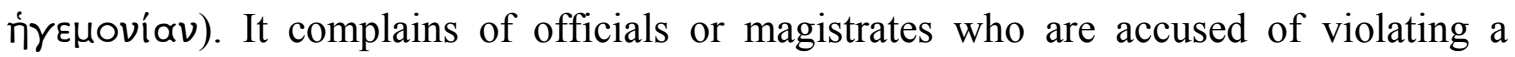
constitution of Marcus Aurelius and Verus and a decision by the ex-prefect Sempronius Liberalis concerning appointments to civic magistracies as well as another imperial constitution concerning veterans and their sons. The exact details are uncertain from what remains, but the petitioner seems to imply that the duration and rank of the magistracy he had voluntarily undertaken were subsequently altered against the terms of his original engagement. Two differently phrased versions of a hypotaxis are preserved, the first deleted by large brackets (perigraphe), ${ }^{5}$ but the relevant constitution of Marcus Aurelius and Verus and the ex-prefect's úmó $\mu \nu \eta \mu \alpha$ were not copied.

The reference to a previously unknown imperial constitution exempting veterans and their sons 〈from all violence and harassment - that is, presumably from compulsory public services - is somewhat surprising. It seems to imply that children of veterans were still enjoying some privileges in the late second century, despite the fact that the children of auxiliary veterans born during their father's service were no longer entitled to Roman citizenship after $140 \mathrm{CE}$ and the veterans themselves had only limited immunity from liturgies in this period (see 4-5 n.). It is possible, of course, that the petitioner is exaggerating his claim or misrepresenting slightly the contents of the constitution to suit his purpose. It is especially suspicious that this constitution was not apparently intended to be cited in the hypotaxis, unlike the constitution on appointments to magistracies, suggesting that it was not directly pertinent to the case. A further possible indication of its

\footnotetext{
5 On the practice see TURNER - PARSONS 1987, 16, and PEARL 1973, 60 (the reference there to P.Mich. VI 387 should be to P.Mich. VI 381; cf. also P.Mich. VI 372). Another example in P.Oxy. LXX 4779 (169).
} 
tenuous relevance is that it seems to relate to liturgies (munera), whereas Claudianus' complaint concerns primarily magistracies (ả $\rho x \alpha i ́$, honores) ${ }^{6}$

The writing runs along the fibres. Left and lower margins are extant.

$1 \quad \pi \alpha$...].]ᄁ........].]

c.?

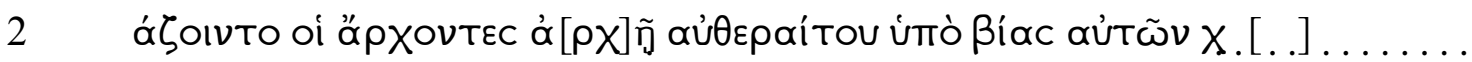

$$
\text { ....... c.? ] }
$$

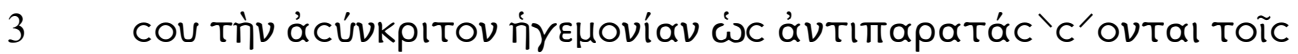

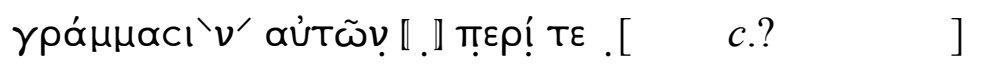

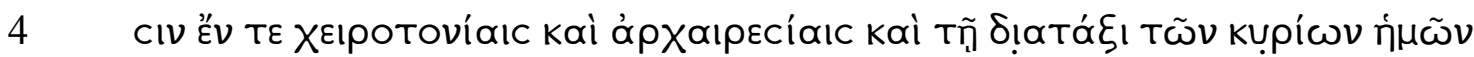

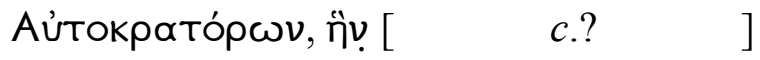

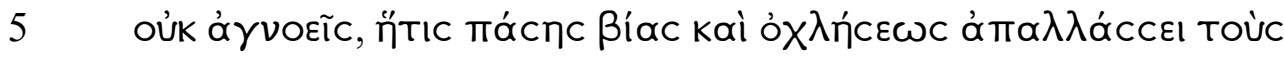

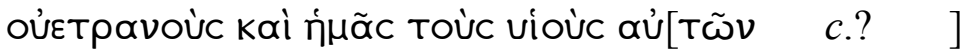

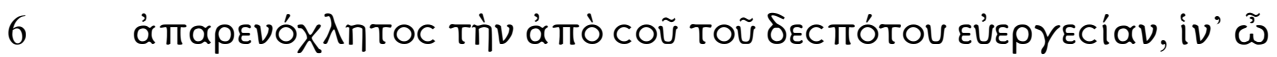

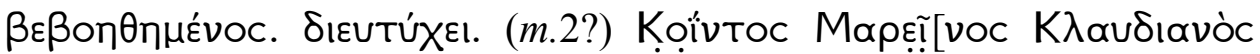

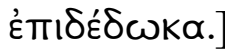

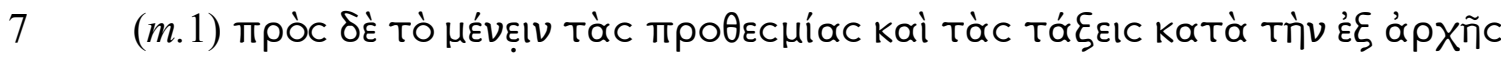
ÚTÓcXEcIV ĖTì Ṭ[ $\quad c .10 \quad$ ]

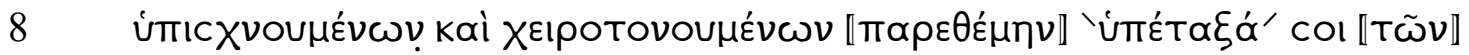

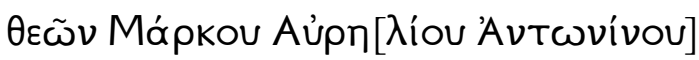

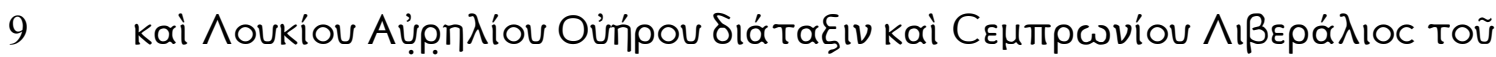

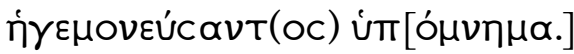

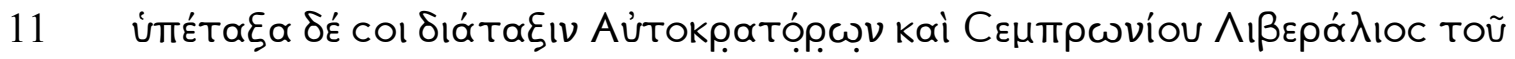

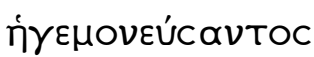

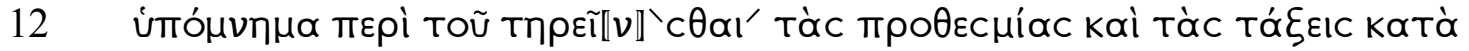

\footnotetext{
${ }^{6}$ On the distinction, cf. Digest 50.4.12 and for the papyri see WILCKEN 1912, 342. The nouns Bía and ö $\chi \lambda \eta c ı c$ and related verbs and adjectives are frequently used to describe illegitimate compulsion and pressure to perform a liturgy.
} 


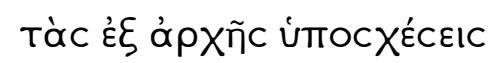

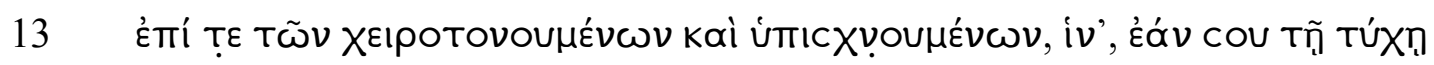

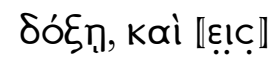

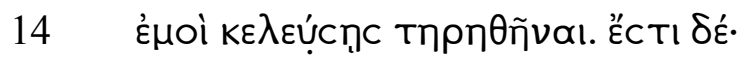

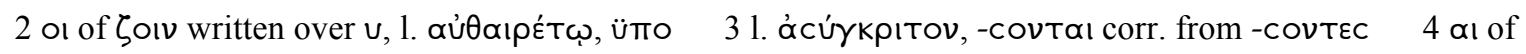

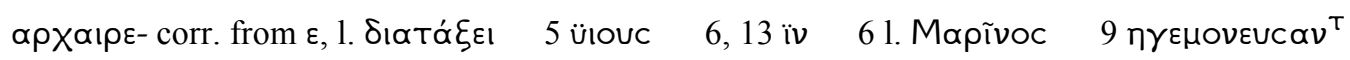

‘... the magistrates would (not?) be ...-ed with a voluntary magistracy against their will ... your incomparable Prefecture, how they array themselves against their writings about both ... in elections and appointments of magistrates, and against the decision of our lords the Emperors, of which ... you are not unaware, which frees veterans and us their children from all violence and harassment ... I unmolested ... the kindness from you, my lord, so that I may obtain help. Farewell.>

(Second hand?) «I, Quintus Marinus Claudianus, have submitted (the petition).〉

(First hand) (In order that, according to the original undertaking (of a magistracy), the fixed periods and ranks remain in place in the case of those ... who undertake (a magistracy) and are elected, I have appended below for you the constitution of the gods Marcus Aurelius Antoninus and Lucius Aurelius Verus and the minute of Sempronius Liberalis, ex-prefect. It is as follows - >

«I have appended for you the constitution of the Emperors and the minute of Sempronius Liberalis, ex-prefect, concerning the observance of the fixed periods and ranks according to the original undertakings in the case of those who are elected and undertake (a magistracy), so that, if it seems good to your Fortune, you may order that they be observed in my case as well. It is as follows -)

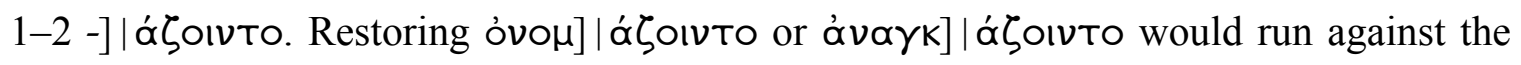
rules of syllabic division across the line and would not work with the following dative.

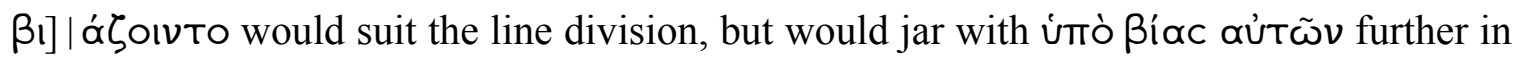

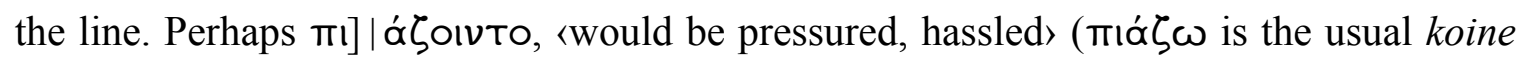

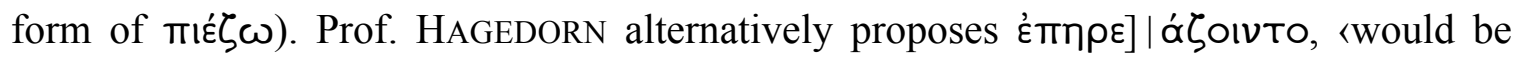


abused>vel sim.; for the frequent use of ĖTńpeı and cognate words to describe the nomination to liturgies of «persons who were not required to serve», see LEWIS ${ }^{2} 1997$, 150 with n. 3, but I could not find any instances of this vocabulary in relation to

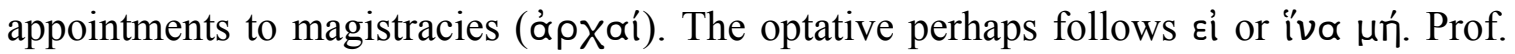
HAGEDORN suggests that «[d]er Optativ könnte vielleicht ein Hinweis darauf sein, daß

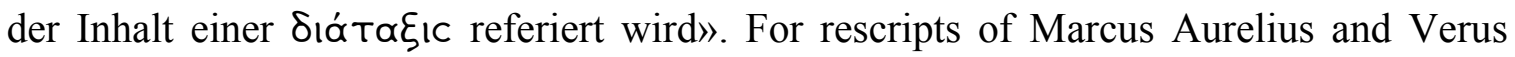
referring to compulsory magistracies, cf. Digest 50.1.38.6 (Papirius), 50.4.6 pr. (Ulpian), and 50.4.11.2 (Modestinus).

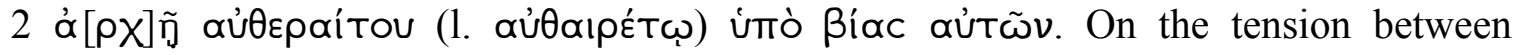
willingness and compulsion to hold magistracies in the Greek cities of the Hellenistic and Roman periods, see generally KLEIJWEGT 1994. The restoration of $\dot{\alpha}[\rho \chi] \tilde{n}$ is due to Prof.

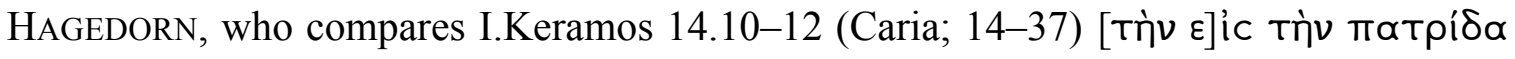

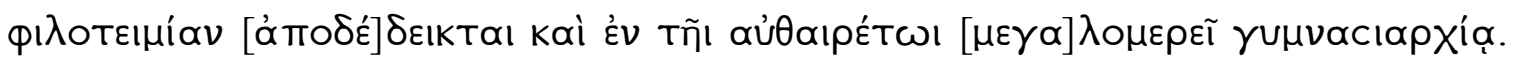
For the interchange of $\omega(\mathrm{l})$ and ou in final position, see GIGNAC 1976, 208-10, 213-4.

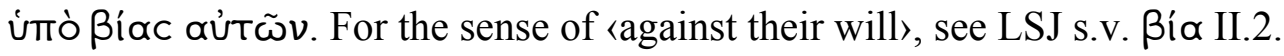

X.[..] ........... Imperfectly preserved letter feet.

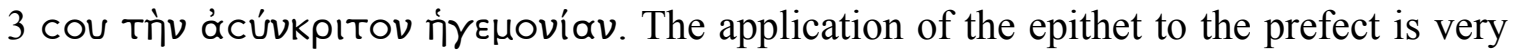
rare in the papyri; cf. perhaps P.Alex. p. 21 no. 310 descr., a fragmentary letter or petition to the prefect with the phrase ] aútòv тñ ácuvkpíţ | [ in line 6. The adjective becomes commoner in private letters of the late third and fourth centuries; see A. PAPATHOMAS, CPR XXV $3.8 \mathrm{n}$.

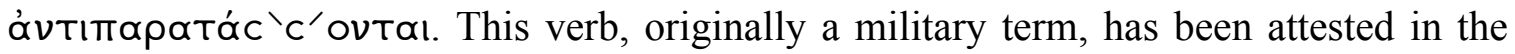

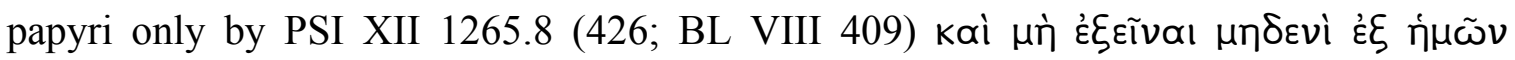
ọv 


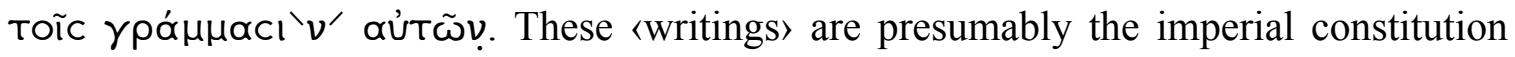
and prefectural úmó $\mu \nu \eta \mu \alpha$ introduced in the hypotaxeis (7-14). That would explain the use of the vaguer word $\gamma \rho \alpha \dot{\mu} \mu \alpha \tau \alpha$, since it can encompass the two different types of

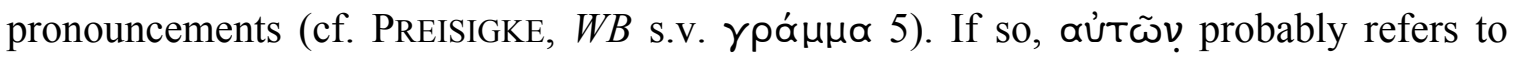
Marcus Aurelius and Verus as well as Sempronius Liberalis.

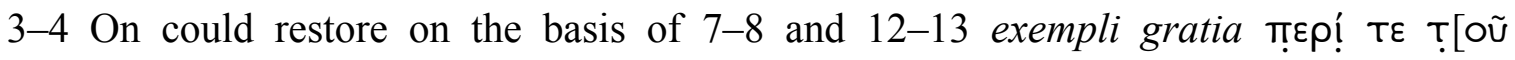

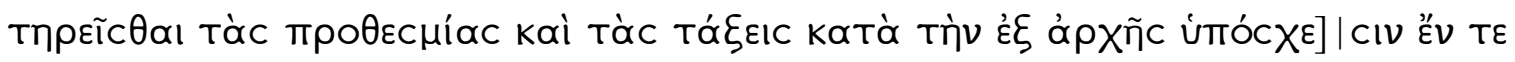

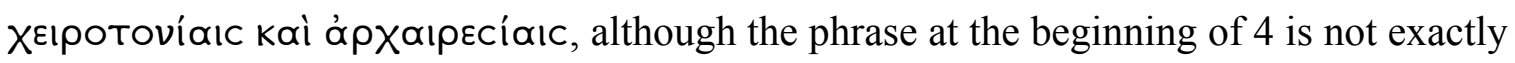

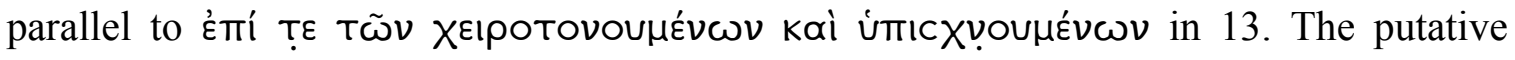
restoration would imply that the lines in the body of the petition were significantly longer than those of the hypotaxeis in 7-14. Line 6 is indecisive, since it is naturally short and nothing is expected after the petitioner's subscription.

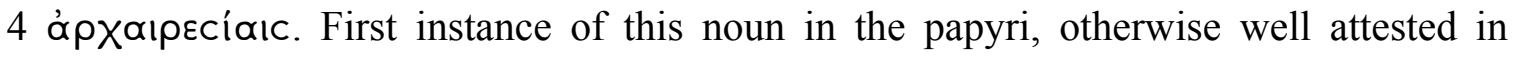

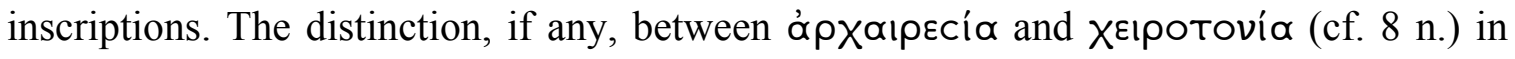

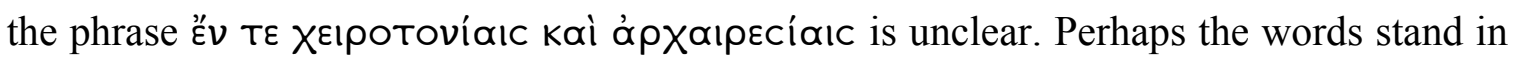
a synonymous relationship, with the second member of the pair specifying the application of the first (appointments to civic magistracies rather than to other offices or liturgies); cf.

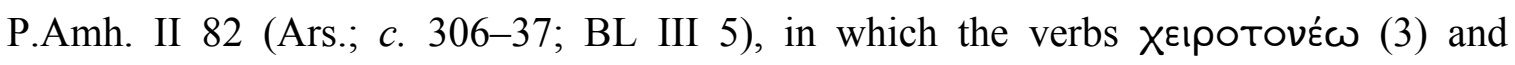

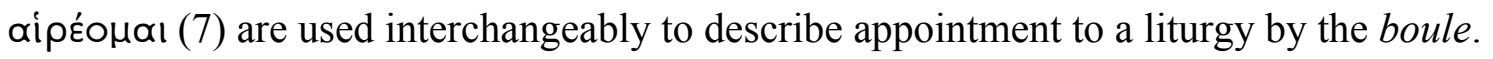

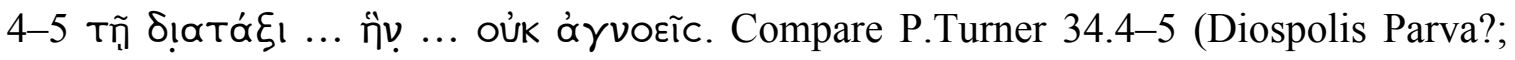

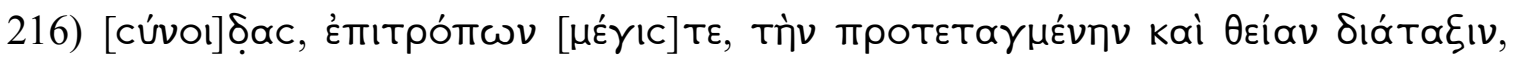

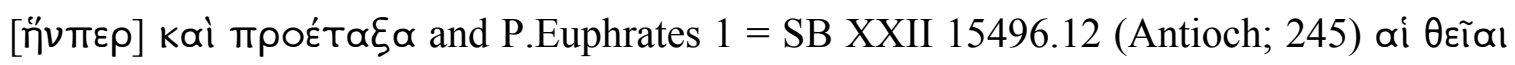

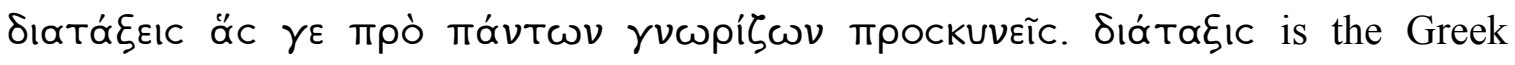
translation of Latin constitutio and designates a pronouncement or decision of the emperor with the force of law; see JÖRDENS 1997, 344-5 (with further bibliography).

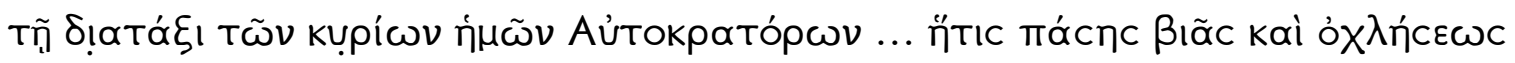

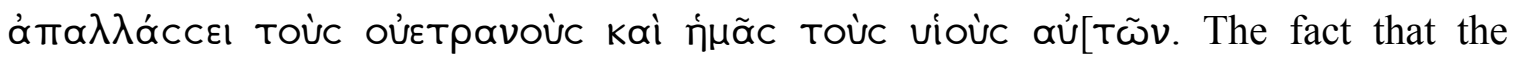


hypotaxeis (7-14) make no mention of veterans and their sons suggests that this is not the same constitution as the one introduced there. If the qualification $\theta \varepsilon \tilde{\omega} \nu$ in the first hypotaxis (8) implies that Marcus Aurelius and Verus were dead, the emperors here would necessarily be different, since the phrase oi Kúpıoı í $\mu \tilde{\omega} \nu$ Aưtokpó торєc ought to designate the living emperors. Under this supposition, the emperors in question would be Septimius Severus and Antoninus (198-211; 209-11 with Geta), since the petitioner's

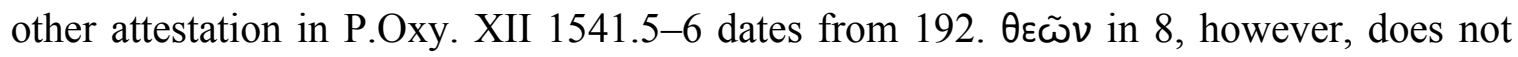
necessarily indicate that Marcus Aurelius and Verus were deceased and is thus not a sufficient reason for attributing this constitution to Severus and his son(s); see below, 8-9 n.

We do not know whether Q. Marinus Claudianus was the son of an auxiliary or legionary veteran, nor whether he was born before, during, or after his father's military service, so that it is difficult to determine his legal status. It is also unclear which, if any, category of veterans is covered by the constitution mentioned here. From $140 \mathrm{CE}$ onwards, the children of auxiliary veterans born during their father's military service no longer enjoyed the right to Roman citizenship; see ECK - WeISS 2001, WAEBENS 2012a, WAEBENS 2012b. If Claudianus was born while his father served in an auxiliary unit (cf. $27 \mathrm{n}$.), and if, as is chronologically likely, his father was discharged after 140, he would not have been a Roman citizen despite his tria nomina. Even in the case of the veterans themselves, the extent of their immunity from liturgies in the first two centuries $\mathrm{CE}$ is not very clear due to the dearth of evidence and the fluctuations of policies from emperor to emperor; see LINK 1989, 66-133, for a discussion of the available evidence and cf. Alston 1995, 62-4, Lewis ${ }^{2} 1997$, 90, 139-40, SChMETterer 2012, 106-11. The petition of the ex-auxiliary veteran Gaius Iulius Apollinarius in BGU I 180 = W.Chr. 396 (Ars.; 172) mentions an imperial constitution that limited veterans' exemption to a period of five years after their discharge. Septimius Severus granted exemption only a muneribus quae non patrimoniis indicuntur. ${ }^{7}$ Even if $\mathbf{1}$ is dated to the reign of Severus and his son(s) (see previous §), the reference here is unlikely to be to the same Severan

\footnotetext{
${ }^{7}$ Digest 50.5.7 (from Book 36 of Papinian's Quaestiones): a muneribus, quae non patrimoniis indicuntur, veterani post optimi nostri Severi Augusti litteras perpetuo excusantur. Munera patrimonii «encumber property and are performed by the payment of money as a contribution to the costs of public works» (BERGER 1953, 589 s.v. Munera); see further NEESEN 1981, 205-9.
} 
constitution: 1) Papinian's one-sentence summary does not mention children of veterans, and indeed the same jurist states in Digest 50.5.8.2 (from Book 1 of his Responsa) that vacationum privilegia non spectant liberos veteranorum; 2) the constitution here is attributed to emperors in the plural, whereas Papinian names only Severus; 3) the Severan constitution relates to munera, while Claudianus' complaint concerns appointments to magistracies ('́) $\rho \alpha$ í, honores), although it is possible that he misappropriated a constitution on munera to support a case relating to compulsory magistracies (see above, 1 introd.).

For sons of veterans as a distinct group recognized by the administration, cf. BGU VII 1634.11 (Ars.; 229/30), where they are apparently listed as exempt from the corvée labour on dikes (see ALSTON 1995, 64).

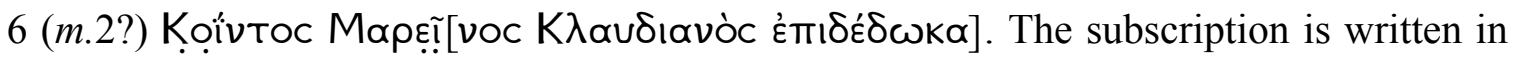
smaller and more cursive letters, but too little remains to be absolutely confident that the hand is different from that of the main text.

Q. Marinus Claudianus has been attested in P.Oxy. XII 1541.5-6 (192) as a contributor to a compulsory state purchase of wheat, where he pays the not insubstantial amount of 50 artabas from his account in the granary of the village Paomis. ${ }^{8}$ The other contributor in that receipt, Dionysia alias Asclatarion, who provides 75 artabas, may have been related to him. 1 reveals that he was the son of a veteran (above, $4-5 \mathrm{n}$.), while 2 shows that he was once a gymnasiarch of Oxyrhynchus - the highest magistracy in the cities of Roman Egypt. To judge from $27 \dot{\varepsilon} \pi\langle\varepsilon\rangle \hat{i} \pi \alpha \rho \varepsilon \pi ı \delta \eta \mu \tilde{\omega}$, he was not a native of Oxyrhynchus, but a relatively new or temporary resident. It is possible that his father settled in Oxyrhynchus at the end of his military service after Claudianus was born. The presence of a son of a veteran among the class of city magistrates is remarkable in view of the lower social status of most veterans attested in Roman Egypt; see SÄNGER 2011, 25-31, who could find only two certain examples of veterans among the «Honoratiorenschicht der Gauhauptstädte» (29), and cf. MiтTHOF 2000, 389-90. Another

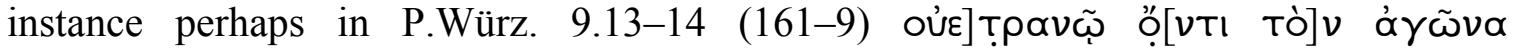

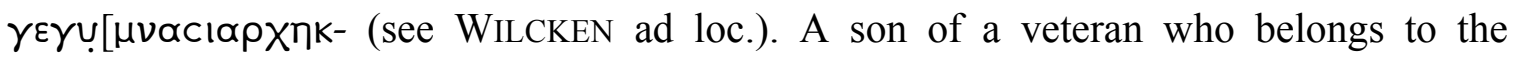

${ }^{8}$ On mupòc cuvaropactikóc (frumentum emptum), see most recently JÖRDENS 2009, 181-211. 
privileged gymnasial class is attested in P.Oxy. XXXVIII 2855.9-14 (291). For the comparable situation in the rest of the empire, see WESCH-KLEIN 1998, 196-200, and HAYNES 2013, 350-55 (KRÓLCZYK 2009 was unavailable to me).

Mapẹ̃][voc. Cf. 2 10 Mapeĩvo[c, P.Oxy. XII 1541.5 Maрєĩvoc. The use of the cognomen Marinus (cf. KAJANTO 1965, 81, 308) as a nomen gentile is unusual but apparently has a parallel in FINK 1971, no. 15 ii.13 (Dura Europos; c. 240). There was also a gentilicium Marinius (Schulze 1904, 188). For the use of cognomina as gentilicia in Roman Greece, cf. DAUX 1977, 409. The name was especially popular in Syria, presumably because of the connection with the Aramaic title mar $=\langle$ lord $\rangle$; see HöRIG SChwertheim 1987, 37 (12-13 n.), 101; Grassi 2012, 222 s.v. Mapeıvoc; CIIP II 1122.2 n.; I.Pal.Tertia Ia 308.3-4 n. (I am grateful to Michael ZelLMANN-RoHRER for some of these references). It is possible that the petitioner's father was originally a recruit from this area who served in a unit stationed in Egypt.

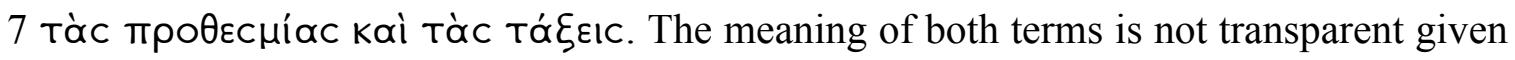
the lack of context. The former presumably refers to the period of office initially agreed upon, although I cannot find any parallels for such a usage. Tákıc perhaps denotes rank (ordo) within the board of magistrates or within a college of multiple holders of a

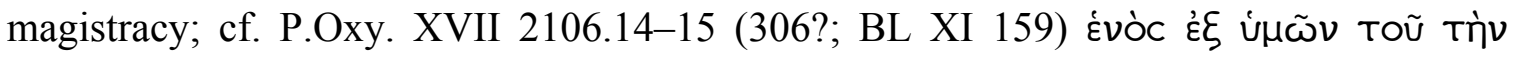

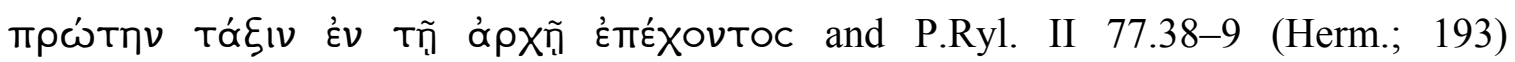

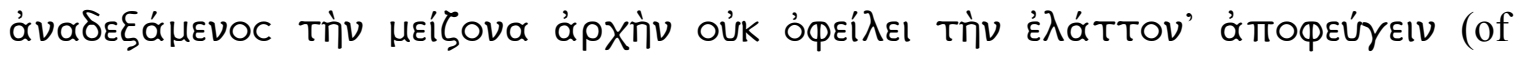
someone refusing to be kosmetes despite having previously accepted to be exegetes, with the implication that the latter magistracy ranked higher than the former). On the «Rangordnung» of municipal magistracies, see W. Habermann, P.Heid. X pp. 375-7 with nn. 13-14.

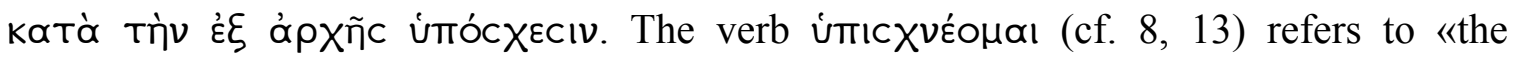
voluntary offer, or promise, to hold the office» (LEWIS 1983, 87); cf. e.g. P.Ryl. II 77.48

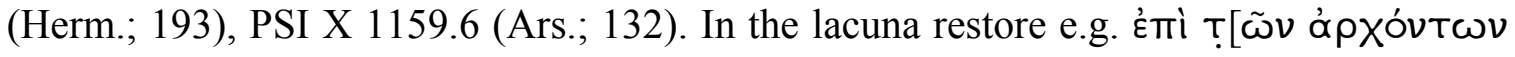
$\tau \tilde{\omega} \nu]$. 
7-14 After c. 200 the citation of supporting imperial constitutions came before the petition proper, not after it as here or in P.Harr. I 67 (c. 150); see HAENSCH 2007, 221-23.

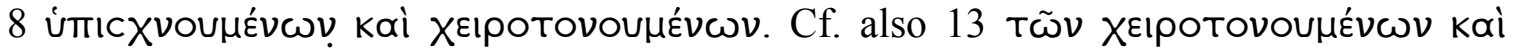

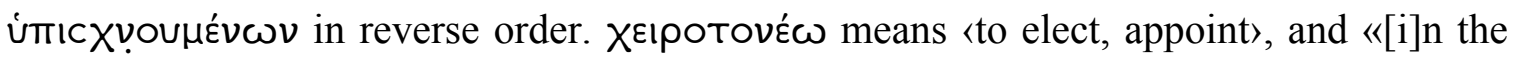
earliest occurrences this verb expresses the action of a strategos or epistrategos» (LEWIS ${ }^{2}$ 1997, 63). «From various documents it is clear that ... magistrates and officials were not popularly elected, but were nominated, if possible from volunteers, by the current (and perhaps past) holders of the post for ratification by the strategos, who could decide whom to appoint in disputed cases» (BOWMAN - RATHBONE 1992, 122, with reference to P.Ryl. II 77 (Herm.; 193); cf. also id. 124 n. 93).

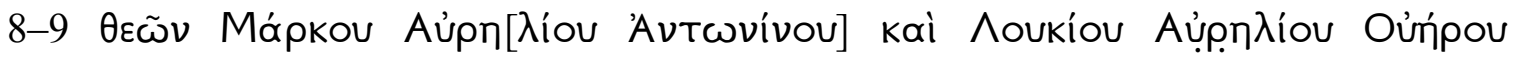

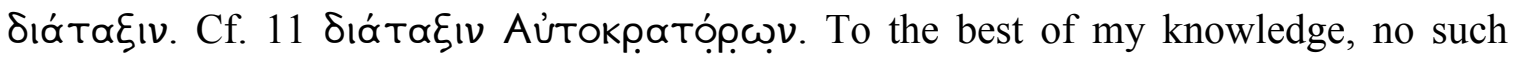
constitution by Marcus Aurelius and Lucius Verus is known. A list of the decisions and pronouncements of Marcus Aurelius cited in the legal codes is given by NOYEN 1954, 366-71. Those of Marcus and Verus preserved in inscriptions and papyri are collected in OLIVER 1989, 336-63 nos. 166-180; cf. also ANASTASIADIS - SOURIS 2000.

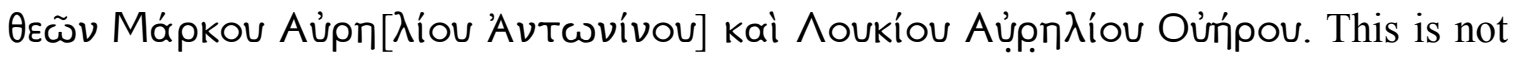
an official imperial titulature and is without parallel in BURETH 1964, 77-82; cf. also the solitary Aưtokp̣ a Tọp̣. give the proper titulature in the fair copy. The qualification $\theta \varepsilon \tilde{\omega} \nu$ need not imply that the emperors are dead, i.e. divi; see Preisigke, $W B$ s.v. Өeóc 5 («Gottkaiser (bei Lebzeiten)»), DE JONG 2006, 247-51, who calls this practice «exceptional» in the papyri (p. 248), and more generally PRICE 1984.

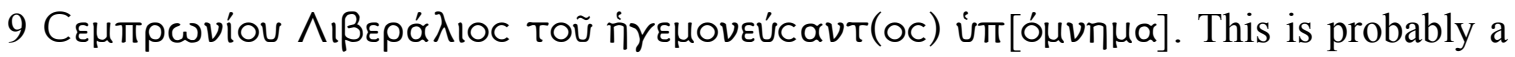
decision of the prefect minuted in his official daybook, usually designated in Greek in the

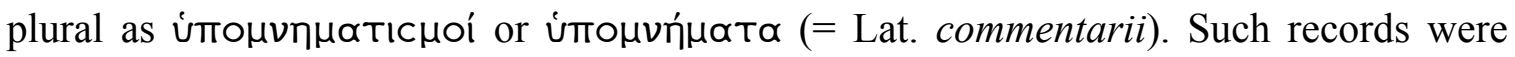


available in state archives for consultation by litigants and are often cited in petitions; see HAENSCH 1992, 219-45, 298-306 (Appendix I). «In this sense the word is usually plural, but not always» (J. D. ThOMAS, P.Oxy. LXXVII 5114.10 n., with examples; cf. also PREISIGKe, $W B$ s.v. 2.c).

11-14 Although the hand of this second hypotaxis is somewhat larger and is written in a more fluid manner and with a sharper pen, it seems to be still the work of the writer of the petition and the first hypotaxis. These lines are also significantly shorter than those of the first hypotaxis, and all end before the right-hand edge of the papyrus. One wonders whether this second hypotaxis was drafted at a later time, after the original piece of papyrus on which the draft petition and the first hypotaxis were written was cut to its current length in order to copy the petition on the back (2). 


\section{Copy of Petition to the Prefect}

P.CtYBR inv. 505(B) $\quad 21(\mathrm{w}) \times 11.1(\mathrm{~h}) \mathrm{cm} \quad$ After 1 April 169 or $201 \mathrm{CE}$
Oxyrhynchus

The conclusion of another petition by Quintus Marinus Claudianus copied on the back of 1. He complains that he did not receive the monies traditionally distributed by the municipal chief priest and the agoranomus to other magistrates (gymnasiarch, exegetes, kosmetes) to help finance the spectacles of the festival of the month Tybi. He requests the addressee to instruct the strategus to assist him in the exaction of the money due to him. The implication is that the petitioner was one of the three magistrates concerned; cf. also

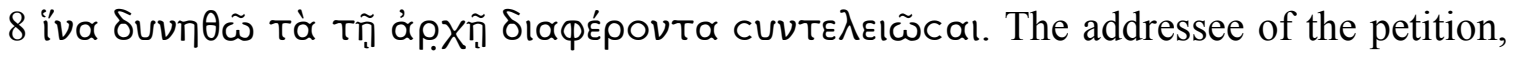
whose identity is not preserved but who must have been the prefect (see $11 \mathrm{n}$. and the Appendix), referred it to the acting epistrategus for a decision. The response of the latter is then appended, granting Claudianus' request and implying that he was a gymnasiarch.

This petition adds to the sporadic evidence for the organization and funding of spectacles in the cities of Roman Egypt. I have collected the following references, presented in chronological order:

- P.Oxy. III $473=$ W.Chr. 33 (Oxyrhynchus or Naucratis; 138-60): ${ }^{9}$ an honorific decree praising a gymnasiarch for various benefactions, among which the fact that

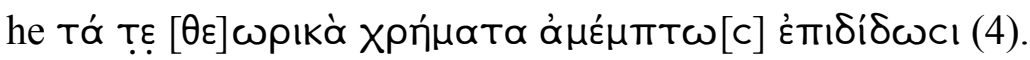

- P.Würz. 9.13-14 (161-9): a very fragmentary petition with the phrase tò]v

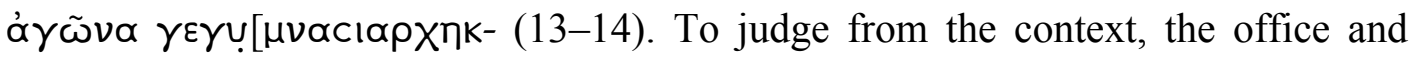
contest were held in Antinoopolis.

- P.Oxy. XVII 2127r (after 171?): a municipal account recording various payments, including a sum of one talent owed apparently by a former exegetes

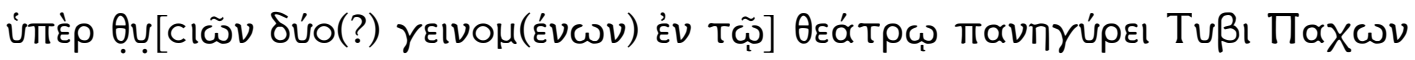
(3-4; cf. 11).

\footnotetext{
${ }^{9}$ LEWIS 1981, 78-80 = BL VIII 235, argued that this papyrus relates to Naucratis, but JöRDENS 2006, 1978 , has reinstated the case for Oxyrhynchus.
} 
- P.Oxy. III 519 = W.Chr. 492 (II): an account for public games and spectacles in which 42 drachmas are said to have been received from the exegetes and 53 drachmas and 1/2 obol from the kosmetes out of a total of 500 drachmas and 1 obol. WILCKEN suspects that the gymnasiarch must also have been named before the break of the papyrus at the top of fr. b. For similar accounts of expenses for spectacles or games, cf. P.Köln. IX 369 (Ars.?; II/III), P.Oxy. VII 1050 (II/III), SB IV 7336 (Ars. or Oxy.; late III), but the source of the payments is not explicit in these documents.

- P.Oxy. X 1333 (II/III): a gymnasiarch orders an unknown addressee, presumably a banker, to pay out 600 drachmas from his account to a certain Copreas $[\lambda]$ ó $\gamma(\omega)$ $\theta \varepsilon \omega$ pik $\tilde{\nu} \nu$ (cf. also below, 3-4 n.). Dated to the fifth year of an unnamed emperor (25 July).

- P.Oxy. VII 1025 = W.Chr. 493 (Euergetis, Cynopolite nome; late III): a gymnasiarch (who is also president of the city council), exegetes, chief priest, and kosmetes invite an actor and a Homeric performer to participate in spectacles (16 $T \tilde{\omega} \nu$ $\theta \varepsilon \omega \rho \tilde{\rho} \tilde{\nu})$ on the occasion of the city's festival in honour of (Cronus〉, promising «the usual payments and presents (19-20).

- SB XIV 11591-2 (Hermopolis; c. 325; BL VIII 372): an official account of expenses, listing inter alia a payment of an uncertain number of talents for

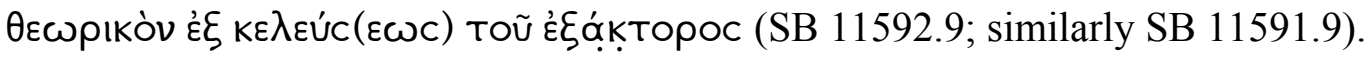

The involvement of the gymnasiarch, exegetes, and kosmetes in the first five documents of the second century tallies with lines $2-4$ of the Beinecke papyrus. ${ }^{10}$ Our text, however, adds the new detail that at least some of the monies for the spectacles were distributed to these three magistrates by the chief priest and the agoranomus. One can imagine that as the expenses of the gymnasiarch, exegetes, and kosmetes at such festivals became onerous in the course of the second century, the Roman administration compelled the other two chief magistrates (the archiereus and the agoranomus) to shoulder part of the burden. In his response, the deputy epistrategus concedes that the number of spectacles

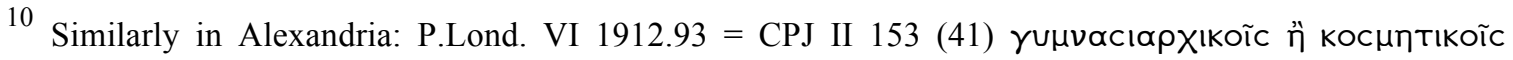

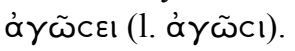


has been reduced: this was presumably the argument made by the chief priest and the agoranomus to justify their non-payment; but he grants Claudianus' request and allows the former practice to resume because of the need to support the ailing gymnasiarchy and for another reason that remains obscure as a result of a lacuna. In the third century, most of these magistrates (except apparently the agoranomus) continue to be involved in the organization and financing of spectacles, but now in the context of the newly created city councils. ${ }^{11}$

The writing runs against the fibres, and the papyrus is complete at the left and foot and partially complete at the right. A number of features show that this is an informal copy: the fact that it is written on the back of $\mathbf{1}$; the lack of a change of hand between the body of the petition, the petitioner's subscription, and the subscription giving the official response; and the presence of abbreviations and a copying mistake (see $3 \mathrm{n}$.).

\footnotetext{
${ }^{11}$ For the association of boule and panegyris, see P.Oxy. XII 1416.2, 11-17 (298; BL VIII 245), P.Oslo III 85 = Pap.Agon. 8 (Oxy.; 273; BL VIII 229); perhaps also P.Oxy. I 41 = W.Chr. 45 (early IV), for which see BOWMAN 1971, 34 n. 45. On the funding of festivals and games in the Egyptian metropoleis, see also the overviews by Perpillou-Thomas 1993, 228-34, and SchmidT 2014, 254-8. For Roman Greece, cf. CAMIA 2011.
} 


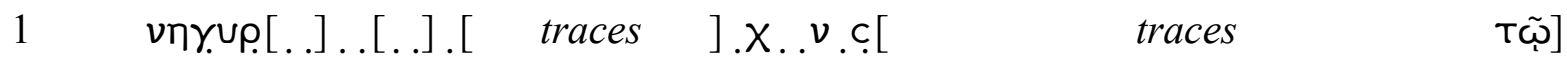

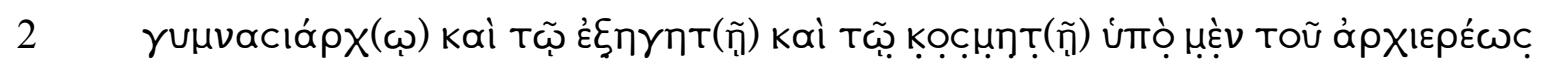
KaTò Tav'̣́-

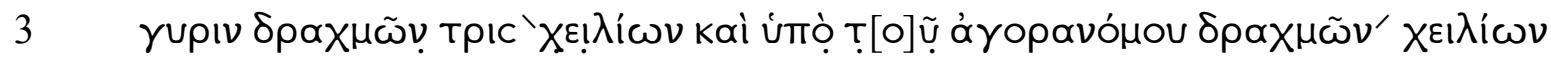

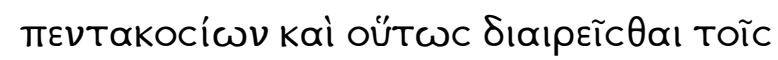

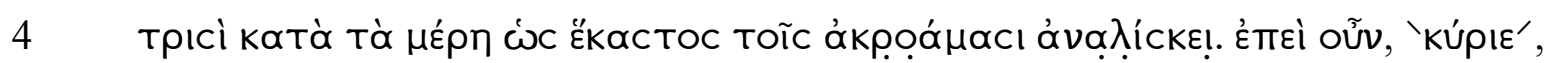

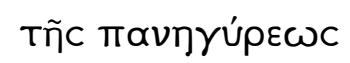

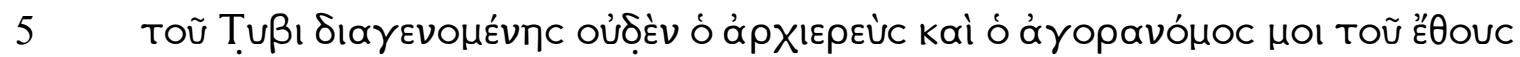

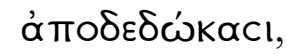

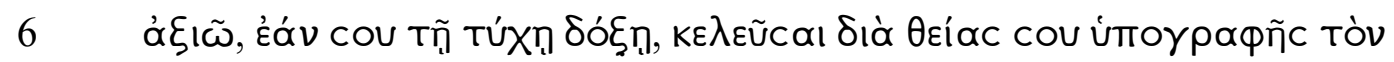

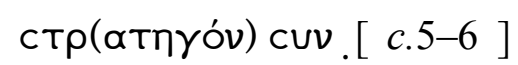

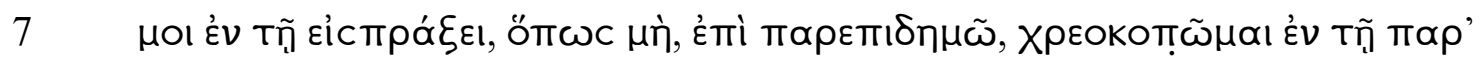

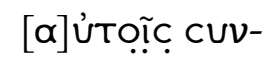

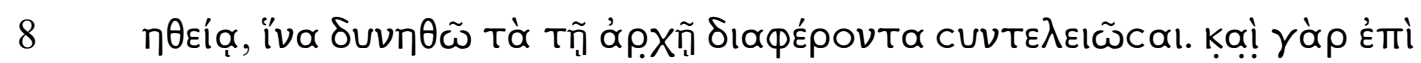

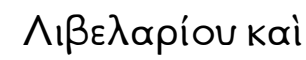

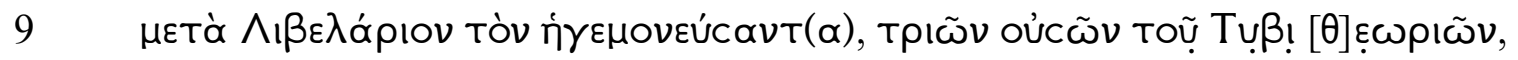
$\pi \alpha \dot{\lambda} \lambda \iota \nabla .[c .3-4]$

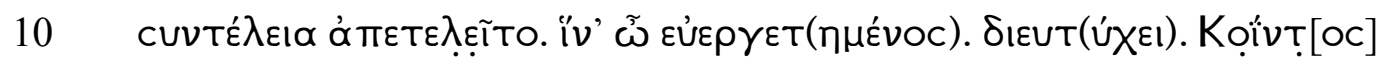

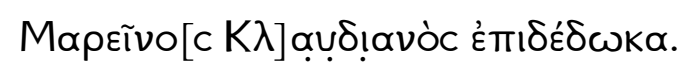

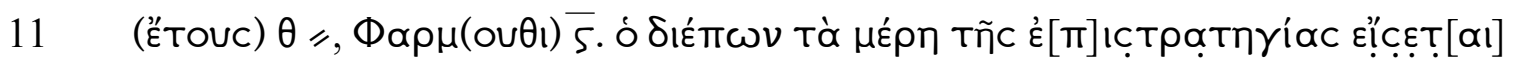

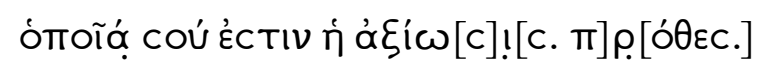

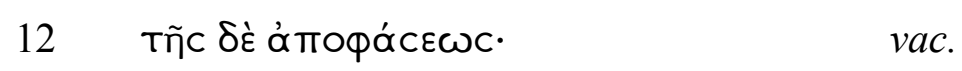

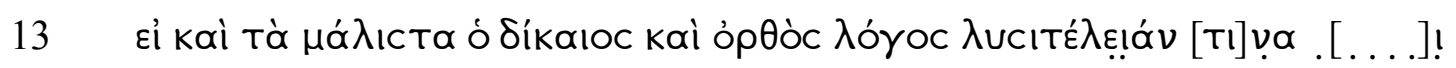

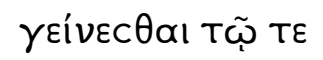

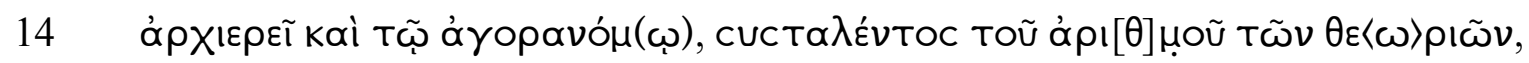

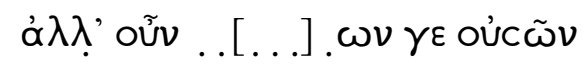

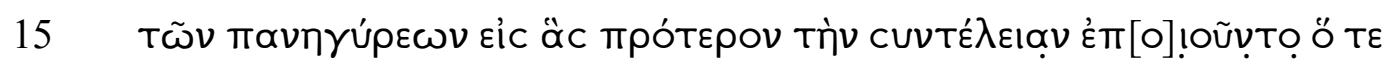

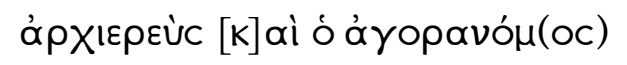

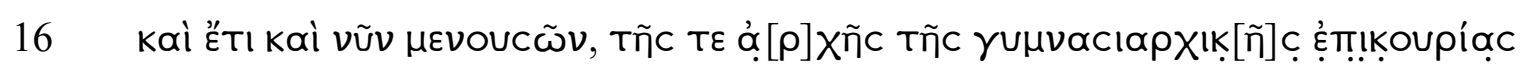

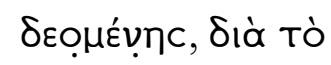


$17 \lambda$ U

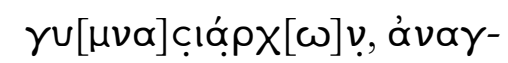

‘... festival ... (a grant to be given?) to the gymnasiarch, the exegetes, and the kosmetes, three thousand drachmas per festival by the chief priest and one thousand and five hundred drachmas by the agoranomus, and thus to be distributed to the three (magistrates) according to the portions that each (of them) spends on the entertainments (or entertainers). Since, therefore, my lord, the festival of Tybi has passed and the chief priest and the agoranomus paid me nothing of the customary (grant), I request, if it seems good to your Fortune, to order the strategus through your divine subscription to assist me in the exaction (of the grant), so that I may not be defrauded in their customary practice, since I am a foreign resident, (and) so that I may be able to fulfil the responsibilities of my magistracy. For both in the time of Liberalis and after Liberalis, the ex-prefect, when there were three Tybi-spectacles, this(?) grant was paid repeatedly. So that I might be benefitted. Farewell.>

〈I, Quintus Marinus Claudianus, have submitted (the petition).〉

«Year 9, Pharmouthi 6. The deputy epistrategus shall become acquainted with whatever your request is. Display publicly.)

«And (the copy) of the decision: «Even if indeed the just and right argument allows(?) some advantage to accrue to the chief priest and the agoranomus, the number of spectacles having been reduced, still, since the festivals to which the chief priest and the agoranomus used to contribute previously are ... and remain so now, and since the magistracy of gymnasiarch is in need of help, because of the advantage to the city of finding a good supply of gymnasiarchs, it is necessary to subtract nothing from the old custom.»» 


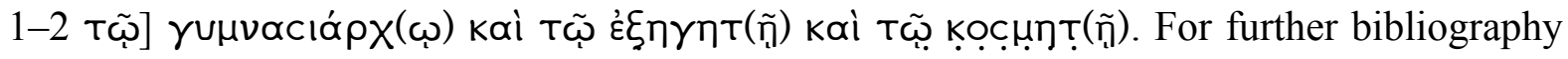
on these three magistracies in Roman Egypt, see HABERMANN 2015, 407 n. 76. «Erst in einem Text aus dem Jahre 113 n.Chr. treten erstmalig die städtischen Funktionsträger Gymnasiarch, Exeget und Kosmet nebeneinander auf und sind gemeinsam mit finanziellen Leistungen für ihr Gemeinwesen im Rahmen der Ausübung ihrer Jahresämter belastet» (id. 406 with reference to P.Lond. III $1177=$ SB XXVI 16652). When they are mentioned together, the usual order of precedence is gymnasiarch, exegetes, kosmetes, as here; cf. W. HabermanN, P.Heid. X pp. 375-7 with nn. 13-14.

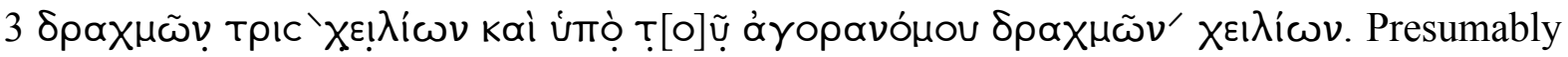
the omission was caused by a saut du même au même ( $\chi \varepsilon 1 \lambda i \omega v)$ in the process of copying.

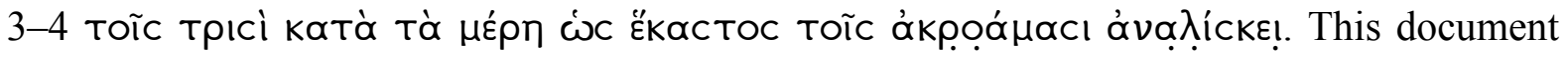
perhaps provides the background for the bank payment of 100 drachmas by an uncertain

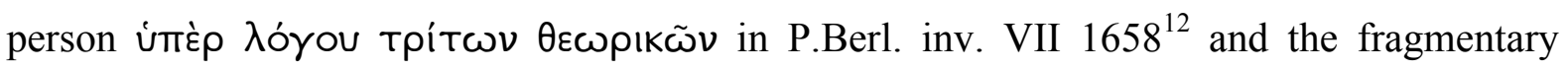

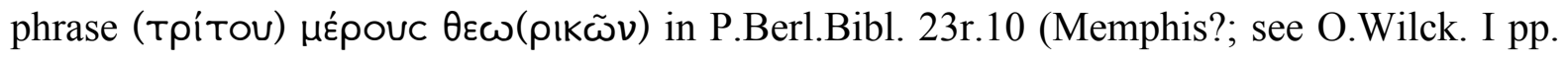
373-4), both of the third century. As Perpillou-Thomas 1993, 229, suspected, these expressions probably imply a tripartite division of expenses between magistrates for the financing of spectacles, a situation confirmed by our text.

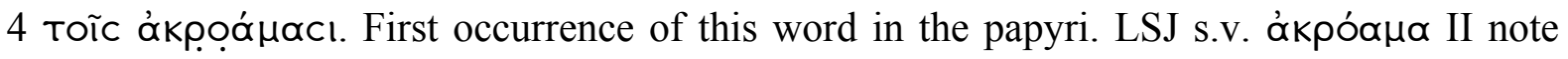
that the plural could designate metonymically the singers or players rather than the music or thing being heard; cf. Polybius 4.20.10, 16.21.12, FD III.2 47.21 (138 BCE), IG II 2153.3 (II), etc. (the same sense in the singular in Cicero: see L\&S s.v. acroama).

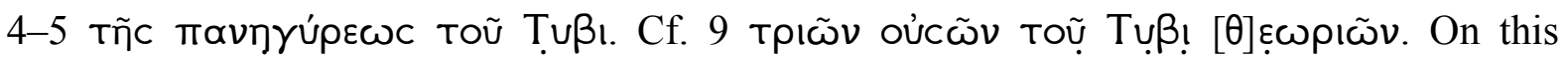
Oxyrhynchite religious holiday, which took place over several days in the second half of the month of Tybi (27/8 December-25/6 January), see Perpillou-Thomas 1993, 146-50.

\footnotetext{
12 Partially transcribed by U. WILCKEN in O.Wilck. I p. 373 but never fully published. I have not been able to obtain an image of the papyrus.
} 
Although Egyptian in origin, the festival had «une forme grecque (sacrifice au théâtre [cf. P.Oxy. 2127r.3-4, quoted in the introd. above], prestations sportives) et des liens étroits avec les manifestations éphébiques du gymnase» (id. 148). This is apparently the first document to attest theatrical-musical performances in connection with it.

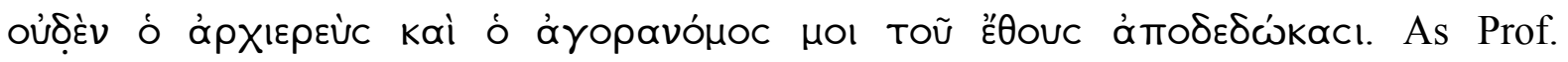

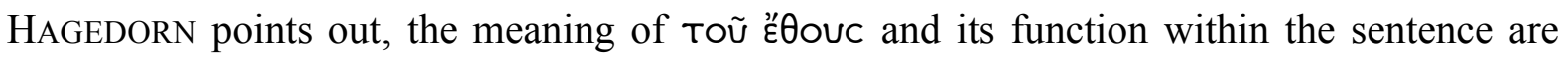
unclear: the genitive is presumably dependent on oưọ́v, but it is odd to say that «they paid

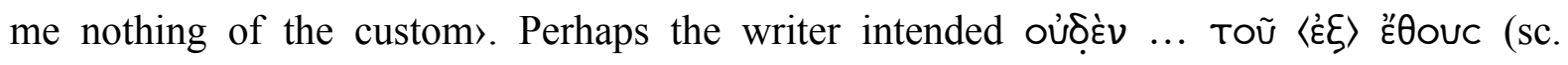

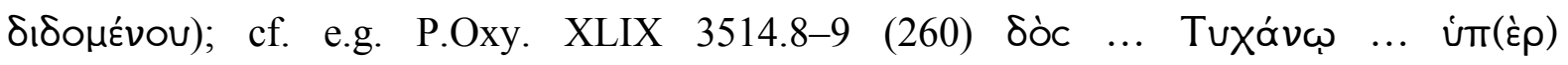

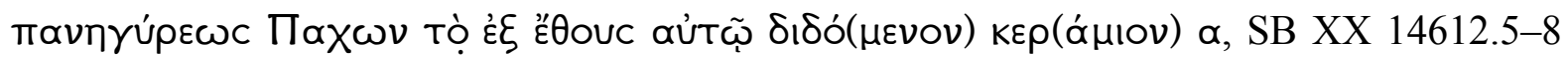

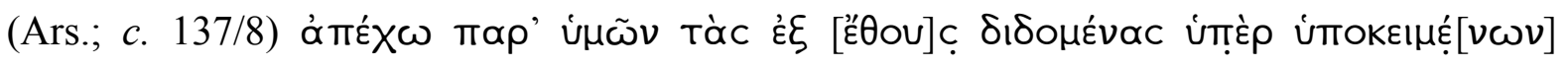

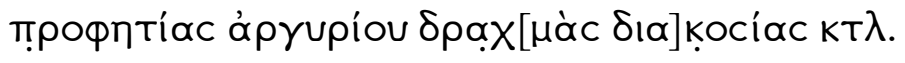

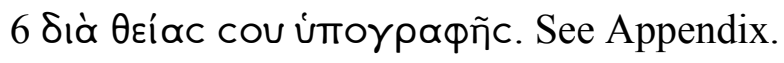

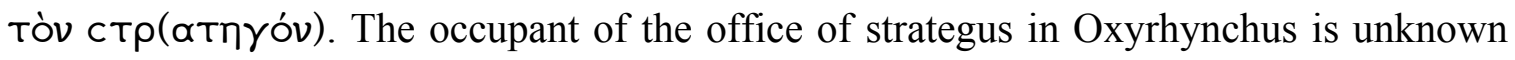
for both 1 April 169 and 1 April 201; see WHITEHORNE ${ }^{2}$ 2006, 98, 101.

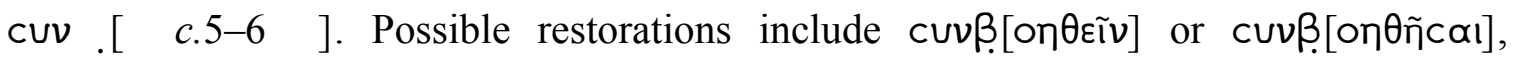

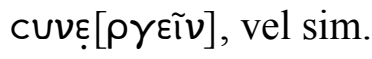

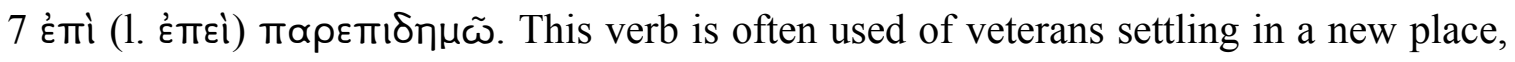
e.g. BGU I 113.12 = W.Chr. 458 (Ars.; 60/61; BL VI 10), P.Oxy. VII 1023.4 (Ars.; 13861), SB IV 7362.7 (Ars.; 188). On the petitioner's status as the son of a veteran, see above, 1 4-5 $\mathrm{n}$. The implication seems to be that Claudianus was born before his father settled in Oxyrhynchus following his discharge.

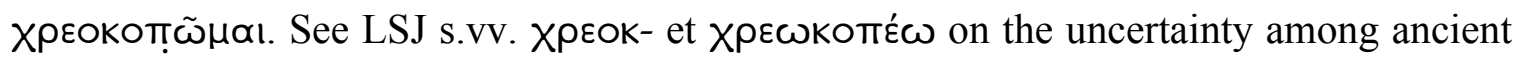
grammarians over whether the word should be spelt with omicron, as usual in this period, or with omega. The verb is rare in the papyri; cf. BGU IV 1208.17 (Heracl.; 27/26 BCE), 


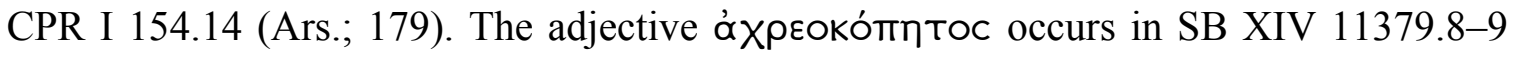
(Ars.; 156; on the date see ZPE 38, 1980, 82), a decision by the prefect Sempronius Liberalis.

$8 \Lambda_{i} \beta \varepsilon \lambda \alpha \rho i o v$. Cf. $9 \Lambda_{i} \beta \varepsilon \lambda \alpha$ piov. For the transposition of lambda and rho in the spelling of Latin names, see GIGNAC 1976, 104.

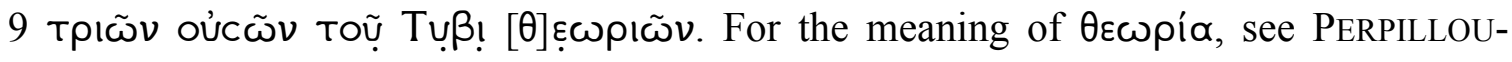
THOMAs 1993, 223-4 and cf. 228-9. The term implies theatrical, musical, and/or dance performances; cf. also 4 toĩc ákpọáu $\mu \alpha c 1$.

It is unclear whether the petitioner means that there were three spectacles at every Tybi-festival (i.e. annually), or that only three spectacles were given altogether since the time of Liberalis. The latter interpretation would imply that such spectacles were only occasionally organized, perhaps because of their high cost. This might explain why the mode of financing them had fallen into oblivion by the time the fourth such spectacle was given by Claudianus and his colleagues. On the other hand, it would seem odd for spectacles marking a major annual festival to be so rarely given. P.Oxy. VII 1025.16= W.Chr. 493 (Euergetis, Cynopolite nome; late III) mentions $\theta \varepsilon \omega p$ pía in the plural for a single festival (غ̇optń) taking place over several days, and this is presented as a regular

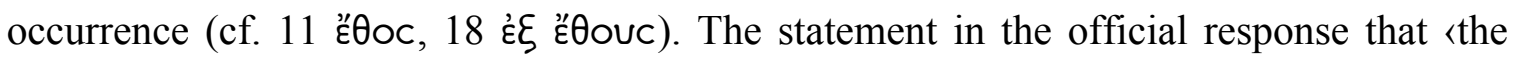
number of spectacles has been reduced (14) is equally ambiguous: it could mean either that there were now fewer spectacles per festival per year or that spectacles were less frequently given at Tybi-festivals over the years.

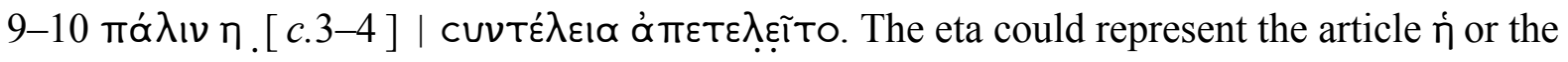

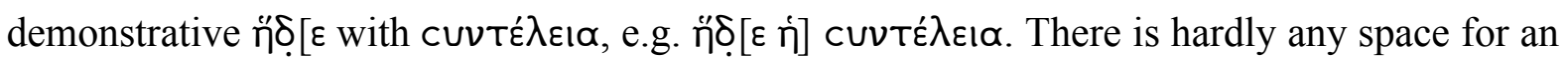
additional word in the lacuna.

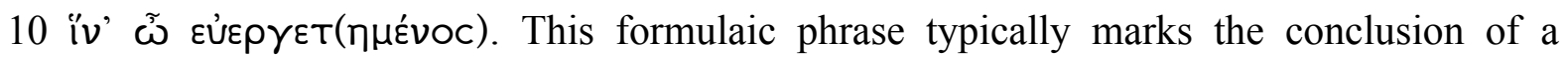
petition, but it is unsyntactical here after the ráp-clause of lines 8-10; note also that it

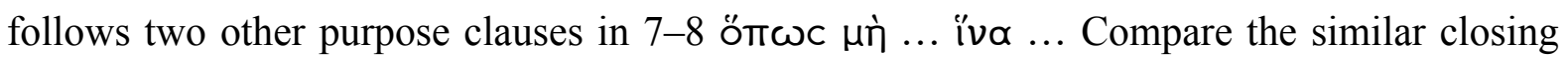


structure of BGU XI 2012.22-7 (Alex.; c. 145-7; on the date see Tyche 16, 2001, 102): ...

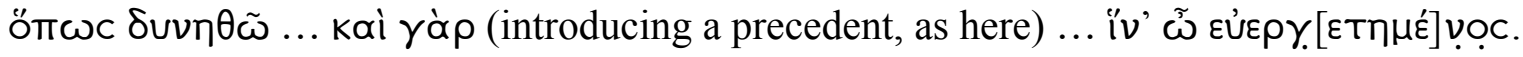

11 (ÉTouc) $\theta=, \Phi \propto \rho \mu\left(\right.$ ou $\left.\theta_{l}\right) \bar{\zeta}$. The date is almost certainly that of the subscription rather than of the petition; see THOMAs 1983, 373-7. The absence of an imperial titulature in dating clauses of such subscriptions is normal. On the identification of the regnal year, see above, general introd.

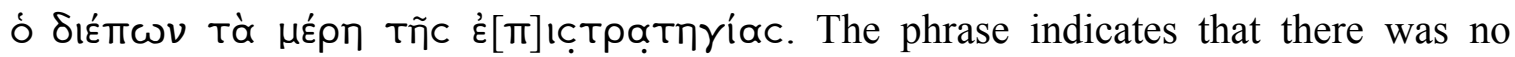
epistrategus in office at the time and his place was temporarily filled by a deputy. For other instances of acting epistrategi, see F. MiтtноF, P.Bingen 107.5-6 $\mathrm{n}$. The fasti of the epistrategi of the Heptanomia are lacunose for both 1 April 169 and 1 April 201 according to THOMAS 1982, 189-90. The petition was referred to the office of the epistrategus probably because of the «special concern which he seems to have had for some or all of the archai», especially the gymnasiarchy; see THOMAS 1982, 94-102 (quote from pp. 94-5).

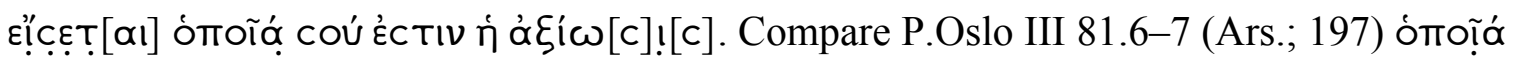

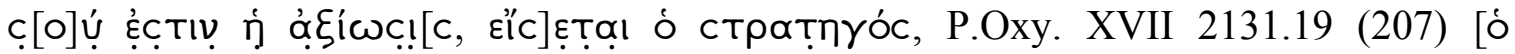

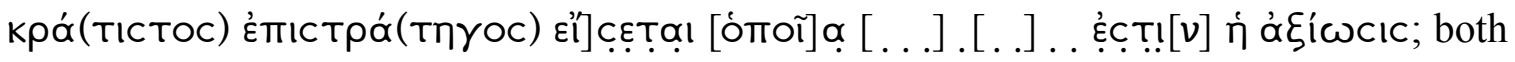
are prefects' subscriptions to petitions.

$\pi] \rho[0 \dot{\theta} \theta \varepsilon c]$. Only the foot of a descender survives, but this is a standard instruction in prefects' subscriptions belonging to Phase IV in HAENSCH's classification, e.g. the aforementioned P.Oxy. XVII 2131.19; see THOMAs 1983, 377-80, HAENSCH 1994, 499507 (esp. 503-4), PAPATHOMAS 1997, 777-8. In this phase, petitions with their respective subscriptions were glued together in a composite roll (tomos synkollesimos), given a sheet number in the roll (kollema), and displayed publicly for the petitioners to copy. The earliest example of a petition processed in this manner is SB XXIV 15915 (164), published by PAPATHOMAS 1997. 


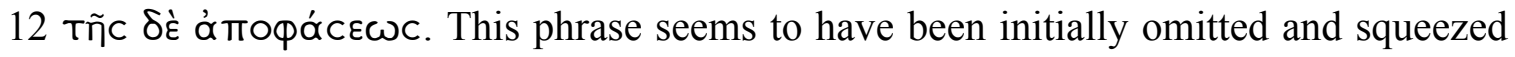
in afterwards. The genitive is implicitly dependent on a word like ávTíypapov, which probably appeared at the beginning of the copy of the petition. ámópacic is the equivalent of Latin sententia; see MASON 1974, 25, 130.

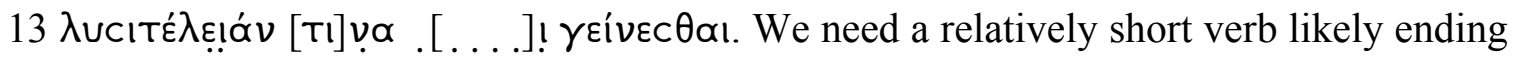
in $-\varepsilon]$ !, capable of governing an infinitive, and meaning «to grant, allow〉 vel sim. The trace before the break is the foot of an ascending oblique compatible with e.g. lambda, mu, or chi (apparently not $\left.\Pi\left[\propto \rho \varepsilon^{\prime} \chi \varepsilon\right] !\right)$. It cannot be completely excluded that ] ${ }^{\circ} \alpha$ is part of the verb, e.g. one beginning with [á] $\mathbf{u}^{\alpha}-$, but alpha is followed by a small blank space, which suggests that a new word follows.

$14 \theta \varepsilon\langle\omega\rangle \rho i \tilde{\omega} v$. For the omission of an unaccented vowel before a liquid, but following a consonant rather than a vowel as here, see GIGNAC 1976, 307-9.

$\dot{\alpha} \lambda \lambda \lambda^{\prime}$ ỡ . . [. . . . . $\omega v \gamma \varepsilon$. For the particle combination $\alpha^{\prime} \lambda \lambda^{\prime}$ ỡ . . . $\gamma \varepsilon$ (a literary touch), see Denniston ${ }^{2} 1954,441-5$. Its usage here corresponds to the sixth in DenNiston's classification: «Apodotic, after concessive conditional clauses, or their equivalent: «even if ..., still» (p. 444). The partly lacunose word must be a predicative adjective agreeing

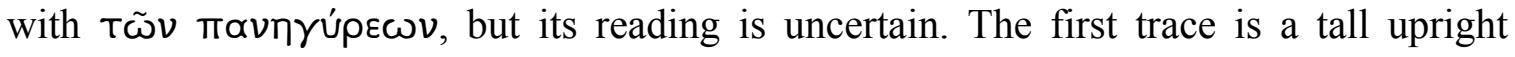
curving to the right; the second is part of a descending oblique; after the small lacuna a thick upright.

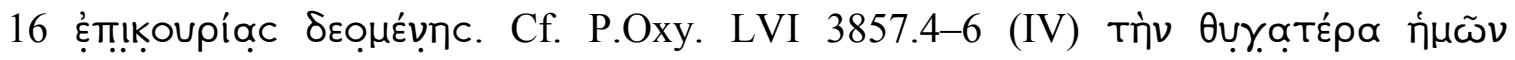

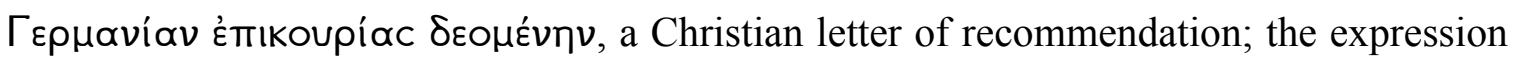
goes back to the Classical period (see LSJ s.v. ÉmıKoupía).

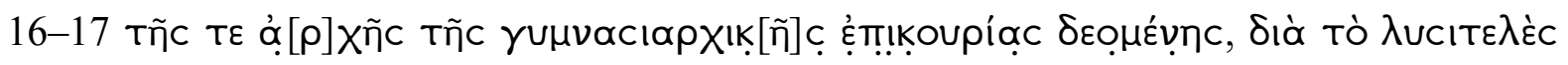

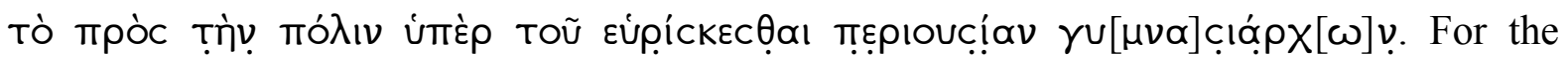
financial pressures on the gymnasiarchy and the Roman administration's concern to ensure a good supply of gymnasiarchs, cf. P.Amh. II 70.2-4 = W.Chr.149 (Herm.; 113-17) тoũ 


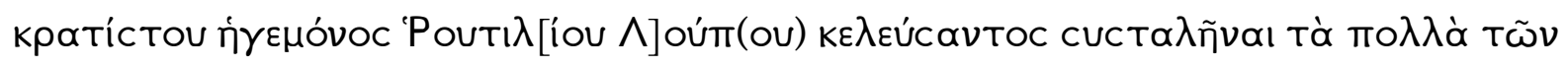

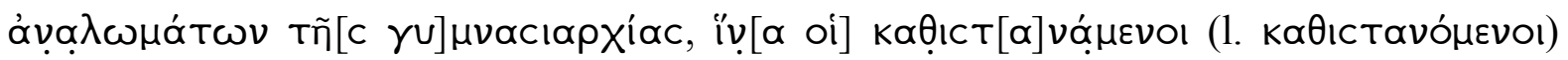

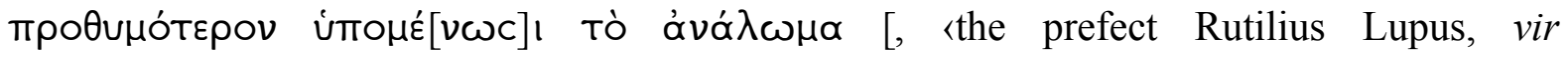
perfectissimus, having ordered the reduction of the greater part of the expenses of the gymnasiarchy, so that those appointed may more readily undertake the expense». 


\section{Appendix: An Imperial Addressee?}

The name and function of the addressee of $\mathbf{2}$ are not extant. In line 6 his subscription is

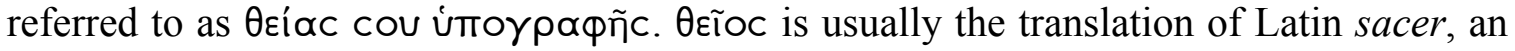
epithet which «is applied to everything connected with the emperor». ${ }^{13}$ For its application to imperial subscriptions, cf. IGBulg IV 2236.79-80 = SEG XLIV $610=$ HAUKEN 1998,

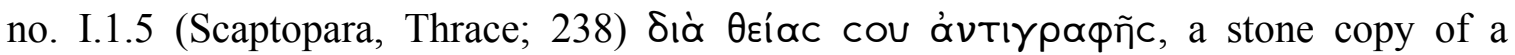
petition addressed to the emperor Gordian III, and SEG LVII 1429.21 = HAUKEN 1998,

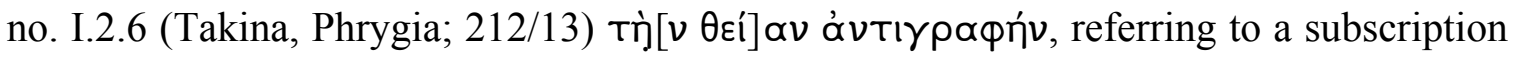
of Antoninus. ${ }^{14}$ Compare the phrases divina subscriptio and sacra subscriptio in CIL VIII 10570 ii.7, iv.13 = ILS $6870=$ HAUKEN 1998, no. I.1.1 (Africa; 181/2), which refer to a subscription of Commodus. The formula usually employed in petitions to prefects or

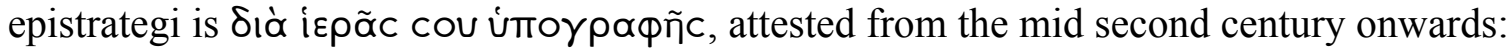
the earliest instances are P.Wisc. I 33.3 (Ars.?; 147) and SB XIV 12087 A.3 (Ars.; 162), the latter referring to an epistrategus. In these cases ípóc is probably the equivalent of

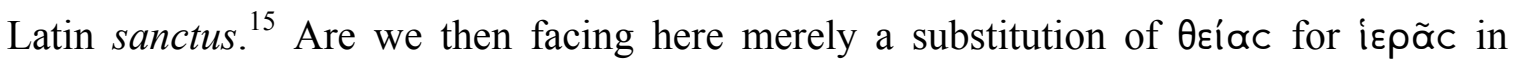
reference to the prefect, ${ }^{16}$ whether as a result of scribal error or rhetorical exaggeration, or could the petition actually have been addressed to an emperor? The former is the simpler assumption, but it seems worthwhile to investigate the latter possibility in greater detail, if only to reject it more confidently.

If the subscription dates from 1 April 201 rather than 1 April 169 (see above, general introd.), it is perhaps not completely inconceivable that the petitioner submitted the complaint to Septimius Severus when the latter resided in Antioch or wherever he was in the Near East at the time (in April 169 Marcus Aurelius was in Rome). But such a scenario would be extremely improbable. Since petitions had to be presented in person or

\footnotetext{
13 BERGER 1974, 53 s.v. 2. On the connotations of the adjective, see generally HILTBRUNNER 1968.

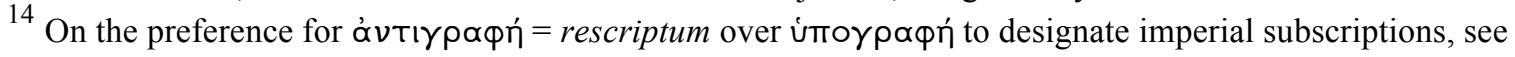
HAUKEN 1998, 302, and cf. NÖRR 1981, 31-2.

15 Cf. HiltbrunNer 1968, 15: «Sanctus ist eben keineswegs ein Synonym von sacer. Sanctus kann man auch von einem Privatmann sagen, um auszudrücken, er sei durch sittliche Integrität und hohe virtus ausgezeichnet.»

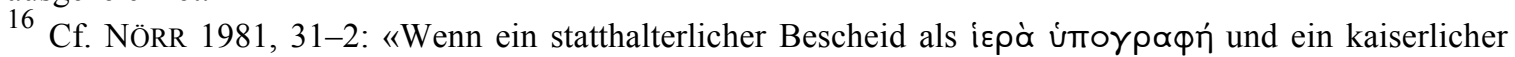
Bescheid als sacra subscriptio bezeichnet werden konnte, so lag Verwechslungsgefahr und Rangvermischung nahe.»
} 
by an agent closely connected to the petitioner, ${ }^{17}$ this hypothesis would imply that Q. Marinus Claudianus undertook a relatively long journey outside Egypt concerning a matter of a mere couple thousands of drachmas. Although the practice and frequency of petitioning emperors by private individuals are well documented, ${ }^{18}$ neither the subject of the petition nor the social standing of the petitioner seem important enough to justify a trip outside the province. The fact that the subscription simply refers the matter back to a procurator in Egypt may not be a decisive objection against such a scenario, for this was common practice in imperial subscriptions in general, even in response to petitions submitted by provincials in Rome; ${ }^{19}$ but it seems very unlikely that it would have been known outside Egypt that only a deputy was occupying the office of the epistrategus at the time. Finally, the Egyptian date of the subscription ought to imply that it was issued in Egypt, unless we posit that the original Roman date was «translated» to an Egyptian one in an informal copy such as this. ${ }^{20}$

Since it would be easier to assume that a petitioner from Oxyrhynchus approached the emperor when the latter was in Egypt, could Severus have been still in the province in the spring of 201? The date of Severus' departure for Syria and his exact whereabouts in March-April 201 are in fact unclear. After the conclusion of his second military campaign in Mesopotamia (197/8) and visits to various parts of Syria, Palestine, and Arabia, the emperor arrived to Egypt with his family in 199, probably towards the end of the year. ${ }^{21} \mathrm{He}$ very likely remained there until sometime after August 200, since the Alexandrian coins of his ninth regnal year, which in Egypt ran from 29 August 200 to 28 August 201, continue to bear a representation of the imperial family on their reverse in honour of the family's presence in Egypt (thereby displacing the local Alexandrian

17 See Williams 1974, 93-8. Cf. also Millar 1977, 475: «The petitioners ... had either to take advantage of the emperor's presence in their vicinity or to travel to where he was.»

${ }^{18}$ See the classic treatment by MiLlar 1977, 240-52, 537-49.

19 Cf. Williams 1974, 96-7: «In the Code there are numerous examples, from the Severan period, of petitioners being referred back to the governor or some other appropriate officer» (instances detailed in $\mathrm{n}$. 84). NÖRR 1981, 6, suspects that the practice of referring petitions to other officials «mag ... in der kaiserlichen subscriptio häufiger geschehen sein, als unsere Quellen es erkennen lassen». For epigraphic examples, cf. TURPIN 1991, 111-14.

20 TURPIN 1991, 107, observes that even «[i]mperial decisions delivered in Egypt were normally given Egyptian dates».

${ }^{21}$ The exact month of his arrival is disputed; see LEWIS 1979 and the further bibliography assembled by MiтTHOF 2001, I 52 n. 59. 
types). ${ }^{22}$ We know that the emperor kept residence in Alexandria until at least late April 200, after which he conducted a tour of the province, visiting Memphis, Thebes, and the southern border (HA Vita Severi 17.4; Cassius Dio 75.13.1; IGR I.5 1113). If a statement in Malalas' chronicle is to be trusted, he seems to have returned to Alexandria before going back to Syria, apparently by sea. ${ }^{23}$

The emperor is often assumed to have left Egypt before the end of 200 and to have been in Syria already at the beginning of 201. But there is little concrete evidence to substantiate this assumption, and we simply do not know when precisely Severus departed from Egypt or where he was on 1 April 201. ${ }^{24}$ Severus and his son Antoninus inaugurated their joint consulship on 1 January 202 in Antioch, which implies that they were in Syria before the end of 201, but this provides us only with a terminus ante quem. ${ }^{25}$ In the spring of 201 Severus may have been still in the Egyptian chora, back in Alexandria, somewhere in the vicinity of Egypt, or in Syria. It is not known whether he stopped by Oxyrhynchus on his way to or back from the Thebaid, but if he did, we would have expected such a visit to be mentioned in the later petition to him and Antoninus by Aurelius Horion, P.Oxy. IV 705 = CPJ II 450 (after 202; BL II 96). ${ }^{26}$ If Severus remained in Egypt as late as April 201, he would have spent a considerably longer time there than has previously been assumed - long enough to become intimately acquainted with the

22 See e.g. VoGT 1924, I 165-7.

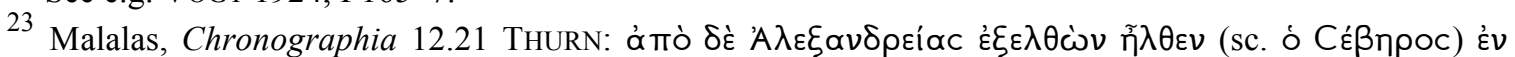

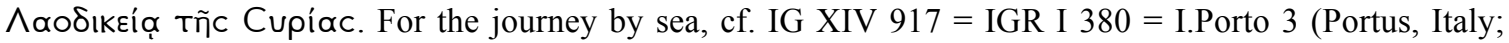
201).

24 Scholars who assume Severus' departure from Egypt in 200: HASEBROEK 1921, 124, stating in n. 2 simply that «Eine längere als einjährige Dauer des Aufenthalts [of Severus in Egypt] möchte ich nicht annehmen»; HANNESTAD 1944, 207-9, proposing a departure between 29 August and 1 October, but on questionable grounds and in the context of a flawed overall chronology of Severus' Egyptian sojourn; HALFMANN 1986, 216-23, esp. 218, 221, arguing merely from absence of evidence after April 200; KIENAST ${ }^{2}$ 1996, 157 («Ende 200(?) Rückkehr nach Syrien»). More circumspect are BIRLEY ${ }^{2} 1988,139$ («He left Egypt by ship for Syria, but neither the exact date nor his precise whereabouts during the year 201 are on record»); BARNES 1989, 255-6 («It is not known when precisely Severus returned to Syria»); CORIAT 1997, 182 n. 30 («A la fin de 200 ou au début de 201, il revint par mer d'Alexandrie en Syrie»).

25 Cf. HA Vita Severi 16.8: dein cum Antiocham transisset, data virili toga filio maiori secum eum consulem designavit, et statim in Syria consulatum inierunt. The narrative in $H A$ is confused at this point and the event is incorrectly placed before the visit to Egypt rather than after it; see HASEBROEK 1921, 118.

${ }^{26}$ This document reveals that Severus honoured the Oxyrhynchites by granting them an audience first after Pelusium upon his arrival in Egypt, and that he esteemed the Oxyrhynchite citizen Aurelius Horion highly enough to be addressed by him and address him in turn by letter; on the latter honour, cf. MILLAR 1977, 216-17. 
administrative, economic, and social problems besetting the province and to institute the substantive and lasting reforms for which his visit is known. ${ }^{27}$

There are, however, several serious objections that can be raised against such a hypothesis:

(i) We have plenty of examples of rescripts and responses by Severus from the period of his Egyptian sojourn; see the lists compiled by HAENSCH 2007, 226-33, and Papathomas 2000, 130, to which add the text published in the latter article, now reprinted as SB XXVI 16787, and P.Oxy. LXXVII 5114. ${ }^{28}$ Where explicit, all were issued when the emperor was staying in Alexandria before his travels south, and all examples whose date is preserved extend from December 199 to April 200. A subscription from April 201 would thus be an outlier. A possibility which cannot be absolutely ruled out is that regnal year $\langle 9\rangle(\theta)$ in our text is a copying error for $\langle 8\rangle(\eta)$, for a date on 1 April 200 would conveniently bring the papyrus in line with the other dated rescripts of Severus. If the document was originally dated to the eighth year but was copied in the ninth year, it is conceivable that a scribe more accustomed to dating by the current year wrote in the latter mechanically.

(ii) Imperial subscriptions to petitions are typically prefaced by the emperor's

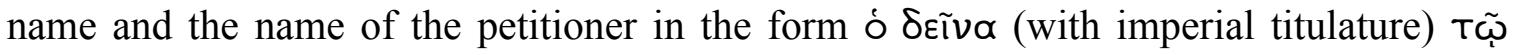
$\delta \varepsilon \tilde{\nu}{ }^{29}{ }^{29}$ The lack of such a formal preface in $\mathbf{2}$ may be attributed to abridgement in the process of copying and the informal nature of the copy, but it could also simply suggest that this is a standard prefect's subscription, where we would not expect an address. ${ }^{30}$ The

\footnotetext{
${ }^{27}$ His most significant reform was, of course, the grant of city councils to Alexandria and the metropoleis of the province, but he left other imprints besides; cf. JÖRDENS 2009, 245: Severus' visit «eine nachhaltige Wirkung in der Bevölkerung hinterließ» (with n. 291 for details); see also HAENSCH 2007, 213-14.

${ }^{28}$ Most of these texts can be conveniently consulted in OLIVER 1989, 444-83 nos. 220-24, 226-43, 248, 250-51, 253, although the identification of some of them as rescripts to petitions is uncertain (see PAPATHOMAS 2000, 130-31, and HAENSCH 2007 for an update and further bibliography). See also the discussion of some Severan rescripts by LEWIS 2002 and more generally CORIAT 1997 on the emperor's judicial and legislative activities.

${ }^{29}$ See e.g. SB XVI 12509.8-9 (130?); CIL III 411.8 = ILS 338 (Smyrna; 139); CIL VIII 10570 iv.1-4 = ILS 6870 = HAUKEN 1998, no. I.1.1 (Africa; 181/2); SEG XXXVII 1186.1-3 = HAUKEN 1998, no. I.2.6 (Takina, Phrygia; 212/13); IGBulg IV 2236.165-6 = SEG XLIV $610=$ HAUKEN 1998, no. I.1.5 (Scaptopara, Thrace; 238); CIL III 14191.2-3 = OGIS II 519 = HAUKEN 1998, no. I.1.6 (Aragua, Phrygia; 244-6). I leave aside imperial rescripts preserved or quoted independently of petitions.

30 On the forms of subscriptions by prefects in this period, see HAENSCH 1994, 493-504, with PAPATHOMAS 1997, 767.
} 
wording of the brief subscription itself has parallels in two other subscriptions by prefects (see 211 n.).

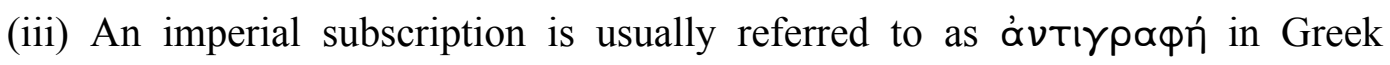

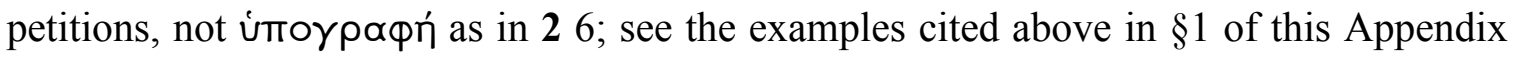
with n. 14.

(iv) Perhaps most decisively, the style and language of the petition may strike one as too routine for such an august addressee as the emperor, although this can be imputed to a local scribe too little familiar with the requisite niceties: note the simple Kúpı $(24)$,

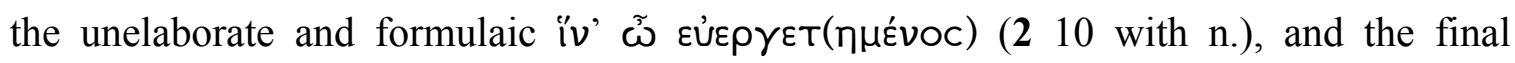

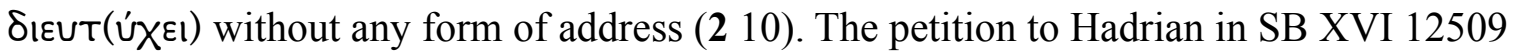
(130?) similarly concludes with a bare SıєuTúX£ (6), but its request is slightly more

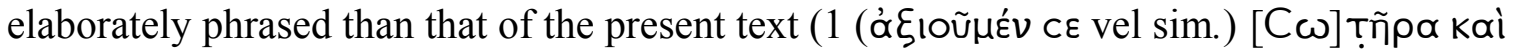

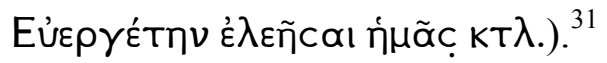

To these objections might be added the lack of mention of a boule in a petition otherwise concerned with magistracies and the city's finances, despite the establishment of this institution by Severus in $200 \mathrm{CE}$. Altogether, these difficulties, the easy semantic overlap between ípóc and $\theta \varepsilon i ̃ o c$, and the possibility of scribal error or the petitioner's desire to flatter the prefect cannot allow us to infer with any confidence that the petition was addressed to Severus and that he remained in Egypt until the spring of 201.

\footnotetext{
${ }^{31}$ For general comparison with the language of other petitions to emperors, cf. P.Coll. Youtie II $66=$ P.Oxy. XLVII 3366 (258; BL IX 58), PSI XIV 1422 (c. 301/2; on the date see P.Oxy. LXXIX p. 170), P.Ryl. IV 617 (Leont.; 317?), and the epigraphic texts reproduced in HAUKEN 1998, although it must be borne in mind that many of these examples are later than 2; cf. also P.Oxy. IV $705=$ CPJ II 450 (after 202; BL II 96).
} 


\section{Bibliography}

Papyrological volumes are cited according to the standard abbreviations of the online Checklist of Editions of Greek, Latin, Demotic, and Coptic Papyri, Ostraca, and Tablets at http://papyri.info/docs/checklist. Abbreviations for epigraphic corpora usually follow Supplementum Epigraphicum Graecum.

Alston, R., 1995, Soldier and Society in Roman Egypt: A Social History.

Anastasiadis, V. I. - Souris, G. A., 2000, An Index to Roman Imperial Constitutions from Greek Inscriptions and Papyri: $27 \mathrm{BC}$ to 284 AD.

BARNES, T. D. , 1989, Emperors on the Move, JRA 2, 247-61.

BERGER, A., 1953, Encyclopedic Dictionary of Roman Law.

Birley, A., ${ }^{2} 1988$, Septimius Severus: The African Emperor.

Bowman, A. K., 1971, The Town Councils of Roman Egypt (ASP 11).

Bowman, A. K. - Rathbone, D., 1992, Cities and Administration in Roman Egypt, JRS $82,107-27$.

Bureth, P., 1964, Les titulatures impériales dans les papyrus, les ostraca et les inscriptions d'Égypte (30 a.C. - 284 p.C.).

Camia, F., 2011, Spending on the Agones: The Financing of Festivals in the Cities of Roman Greece, Tyche 26, 41-76.

CORIAT, J.-P., 1997, Le prince législateur: La technique législative des Sévères et les méthodes de création du droit impérial à la fin du principat. 
DAUX, G., 1977, L'onomastique romaine d'expression grecque, in: N. DUVAL - H.-G. Pflaum (eds.), L'onomastique Latine, 405-17.

Denniston, J. D., ${ }^{2} 1954$, The Greek Particles, $2^{\text {nd }}$ ed. revised by K. J. Dover.

ECK, W. - WeISS, P., 2001, Die Sonderregelungen für Soldatenkinder seit Antoninus Pius. Ein niederpannonisches Militärdiplom vom 11. Aug. 146, ZPE 135, 195-208.

FAORO, D., 2016, I prefetti d'Egitto da Augusto a Commodo.

FINK, R. O., 1971, Roman Military Records.

GignaC, F. T., 1976, A Grammar of the Greek Papyri of the Roman and Byzantine Periods. Vol. 1: Phonology.

GonIs, N., 2009, Egypt and the Date of the Death of Lucius Verus, ZPE 169: 196.

GraSSI, G. F., 2012, Semitic Onomastics from Dura Europos: The Names in Greek Script and from Latin Epigraphs.

HabermanN, W., 2015, Aspekte des römerzeitlichen Gymnasiums in Ägypten, APF $61 / 2,384-423$.

HAENSCH, R., 1992, Das Statthalterarchiv, ZRG 109, 209-317.

Haensch, R., 1994, Die Bearbeitungsweisen von Petitionen in der Provinz Aegyptus, ZPE 100, 487-564. 
Haensch, R., 2007, Apokrimata und Authentica: Dokumente römischer Herrschaft in der Sicht der Untertanen, in: R. HAENSCH - J. HeINRICHS (eds.), Herrschen und Verwalten, $213-33$.

Halfmann, H., 1986, Itinera principum: Geschichte und Typologie der Kaiserreisen im Römischen Reich.

Hannestad, K., 1944, Septimius Severus in Egypt: A Contribution to the Chronology of the Years 198-202, Classica et Medievalia 6, 194-222.

HASEBROEK, J., 1921, Untersuchungen zur Geschichte des Kaisers Septimius Severus.

Hauken, T., 1998, Petition and Response.

Haynes, I., 2013, Blood of the Provinces: The Roman Auxilia and the Making of Provincial Society from Augustus to the Severans.

HiltbrunNer, O., 1968, Die Heiligkeit des Kaisers (Zur Geschichte des Begriffs sacer), Frühmittelalterliche Studien 2, 1-30.

HöRIG, M. - SchwertheIM, E., 1987, Corpus cultus Iovis Dolicheni.

DE Jong, J., 2006, Egyptian Papyri and «Divinity» of the Roman Emperor, in: L. DE BLOIS et al. (eds.), The Impact of Imperial Rome on Religions, Ritual, and Religious Life in the Roman Empire, 239-52.

JÖRDENS, A., 1997, Erlasse und Edikte, in: G. ThüR - J. VÉLISSAROPOULOSKarakostas (eds.), Symposion 1995: Vorträge zur griechischen und hellenistischen Rechtsgeschichte, 325-52. 
Jördens, A., 2006, Der praefectus Aegypti und die Städte, in: A. Kolb (ed.), Herrschaftsstrukturen und Herrschaftspraxis, 191-200.

JÖRDENS, A., 2009, Statthalterliche Verwaltung in der römischen Kaiserzeit: Studien zum praefectus Aegypti.

KaJAnto, I., 1965, The Latin Cognomina.

KIENAST, D., ${ }^{2}$ 1996, Römische Kaisertabelle.

KleiJwegt, M., 1994, «Voluntarily, but Under Pressure»: Voluntarity and Constraint in Greek Municipal Politics, Mnemosyne 47, 64-78.

KRÓLCZYK, K., 2009, Veteranen in den Donauprovinzen des Römischen Reiches.

LewIS, N., 1995, When did Septimius Severus reach Egypt?, Historia 28, 253-4 = On Government and Law in Roman Egypt (ASP 33), 1995, 242-3.

LEWIS, N., 1981, Notationes legentis, BASP 18, 73-81.

LewIS, N., 1983, The Metropolitan Gymnasiarchy, Heritable and Salable, ZPE 51, 85-91.

LewIS, N., ${ }^{2} 1997$, The Compulsory Public Services of Roman Egypt (Pap.Flor. XXVIII).

LEwIS, N., 2002, Ex minimis ... lux: De l'estimation actuelle du régime des Sévères, CE 77, 289-94.

LINK, S., 1989, Konzepte der Privilegierung römischer Veteranen.

Mason, H. J., 1974, Greek Terms for Roman Institutions (ASP 13). 
MiLlaR, F., 1977, The Emperor in the Roman World (31 BC - AD 337).

Mitthof, F., 2000, Soldaten und Veteranen in der Gesellschaft des römischen Ägypten (1.-2. Jh. n. Chr.), in: G. AlfÖLdY - B. Dobson - W. ECK (eds.), Kaiser, Heer und Gesellschaft in der Römischen Kaiserzeit. Gedenkschrift für Eric Birley, 377-405.

Mitthof, F., 2001, Annona Militaris: die Heeresversorgung im spätantiken Ägypten (Pap.Flor. XXXII).

NeEsen, L., 1981, Die Entwicklung der Leistungen und Ämter (munera et honores) im römischen Kaiserreich des zweiten bis vierten Jahrhunderts, Historia 30, 203-35.

NöRR, D., 1981, Zur Reskriptenpraxis in der hohen Prinzipatszeit, ZRG 98, 1-46.

NoYen, P., 1954, Divus Marcus: princeps prudentissimus et iuris religiosissimus, Revue internationale des droits de l'antiquité $3^{\mathrm{e}}$ série no. 1, 349-71.

Oliver, J. H., 1989, Greek Constitutions of the Early Roman Emperors from Inscriptions and Papyri.

Papathomas, A., 1997, Eine Petition an den praefectus Aegypti aus der friedlichsten und glücklichsten Regierungszeit von Marcus Aurelius und Verus (P.Heid. Inv. G 73), in: B. KRAMER et al. (eds.), Akten des 21. Internationalen Papyrologenkongresses (APF Beiheft 3), 765-79.

Papathomas, A., 2000, Ein neues Reskript der Kaiser Septimius Severus und Caracalla, ZPE 131, 129-34.

Pearl, O. M., 1973, Part of a Daybook of Payments in Kind, ZPE 10, 55-62. 
Perpillou-Thomas, F., 1993, Fêtes d'Égypte ptolémaïque et romaine d'après la documentation papyrologique grecque (Studia Hellenistica 31).

PRICE, S. R. F., 1984, Gods and Emperors: The Greek Language of the Roman Imperial Cult, JRS 104, 79-95.

SÄNGER, P., 2011, Veteranen unter den Severern und frühen Soldatenkaisern: Die Dokumentensammlungen der Veteranen Aelius Sarapammon und Aelius Syrion.

SchmettereR, CH., 2012, Die rechtliche Stellung römischer Soldaten im Prinzipat.

SchmidT, S., 2014, Stadt und Wirtschaft im Römischen Ägypten: die Finanzen der Gaumetropolen.

SCHUlzE, W., 1904, Zur Geschichte lateinischer Eigennamen.

Thomas, J. D., 1982, The Epistrategos in Ptolemaic and Roman Egypt. Part 2: The Roman Epistrategos.

Thomas, J. D., 1983, Subscriptiones to Petitions to Officials in Roman Egypt, in: E. VAN'T DACK et al. (eds.), Egypt and the Hellenistic World, 369-82.

TURNER, E. G., 1987, Greek Manuscripts of the Ancient World, $2^{\text {nd }}$ ed. revised and enlarged by P. J. PARsons (BICS Suppl. 46).

TURPIN, W., 1991, Imperial Subscriptions and the Administration of Justice, JRS 81, $101-18$.

Vogt, J., 1924, Die alexandrinischen Münzen: Grundlegung einer alexandrinischen Kaisergeschichte. 
Waebens, S., 2012a, Imperial Policy and Changed Composition of the Auxilia: The «Change in A.D. 140» Revisited, Chiron 42, 1-23.

Waebens, S., 2012b, Reflecting the «Change in A.D. 140»: The Veteran Categories of the Epikrisis Documents Revisited, ZPE 180, 267-77.

WesCh-KleIn, G., 1998, Soziale Aspekte des römischen Heerwesens in der Kaiserzeit.

Whitehorne, J., ${ }^{2} 2006$, Strategi and Royal Scribes of Roman Egypt (Pap.Flor. XXXVII).

WilcKen, U., 1912, Grundzüge und Chrestomathie der Papyruskunde. Erster Band: Historischer Teil. Erste Hälfte: Grundzüge.

Williams, W., 1974, The Libellus Procedure and the Severan Papyri, JRS 64, 86-103.

\author{
Amin Benaissa \\ Lady Margaret Hall, Oxford \\ United Kingdom \\ amin.benaissa@classics.ox.ac.uk
}

